\title{
Base metal-enriched gold-quartz veins in the eastern Camer- oon goldfields, West-Central Africa
}

\author{
${ }^{1}$ Department of Geology, Pan African University Life and Earth Sciences Institute (PAULESI), University of Ibadan, Ibadan, Nigeria; \\ *Corresponding author, E-mail: bryanngatcha@gmail.com \\ ${ }^{2}$ Department of Geology, Mining and Environmental Science, The University of Bamenda, P.O. Box 39, Bamenda, North West Region, Cameroon \\ ${ }^{3}$ Economic Geology Unit, Department of Geology, University of Buea, P.O. Box 63 Buea, South West Region, Cameroon \\ ${ }^{4}$ Department of Earth and Environmental Sciences, Botswana International University of Science and Technology, Private Bag 16, Palapye, Botswana \\ ${ }^{5}$ Spectrum, University of Johannesburg, PO Box 524, Auckland Park 2006, Johannesburg, South Africa
}

(Received: March 7, 2021; Revised accepted: July 19, 2021)

https://doi.org/10.18814/epiiugs/2021/021019

The Colomine and Bétaré Oya gold districts are among the main gold-producing districts in the reworked Paleoproterozoic terrain of eastern Cameroon. The characteristics of the mineralized and barren veins from these areas were investigated with the aim of helping artisanal gold miners and Small and Medium Size Enterprises (SME) active in the region to identify new gold targets. This could help boost the country's annual gold production and also generate local revenue for the indigenous community. Gold mineralization occurs in gently dipping $N N E-S S W$ to $N E-S W$-trending quartz veins hosted by hydrothermally altered granitic rocks in the Colomine gold district and weathered mica schist in the Bétaré Oya gold district. The hydrothermally altered granite wallrock hosts millimetric-sized quartz lamellae/veinlets characterised by a quartz-sericite-muscovite-biotite \pm chlorite \pm albite assemblage. The mineralized quartz veins in both districts are fractured, brecciated, sheared, and vuggy, characterised by a quartz \pm gold \pm sulphide \pm hematite \pm limonite \pm goethite \pm carbonate assemblage. Hematite occurs in a botryoidal form, ind icating the strong influence of supergene processes. This alteration phase is associated with supergene gold enrichment in the veins and constitutes the most attractive part to be exploited by artisanal and SMEs. The barren veins trend $N W-S W$ to $N-S$ and are generally massive to foliated. Gold ranges between 5 and $32 \mathrm{ppb}$ in the wall-rock and up to 2070 and 4600 ppb in hematite-bearing quartz veins. Bulk geochemistry reveals $\mathrm{Au}-\mathrm{Mo}( \pm \mathrm{Ag})$ element association in Colomine and $\mathrm{Au}-\mathrm{Ag}-\mathrm{Mo}-\mathrm{Cu}$ in Bétaré Oya indicative of a sulfide-bearing granitic source.

\section{Introduction}

A broad spectrum of ore deposits is structurally controlled and the host structures include faults, fractures, folds, and shear zones. These structures provide pathways for the circulation of fluids and sites for the deposition of minerals. The location of Cameroon within the PanAfrican Central African Shear Zone (Fig. 1a) network provides an opportunity to understand shear zone-related mineralization and possibly correlate it with deposits within the Braziliano network in NE Brazil and other parts of the world. The CASZ hosts gold deposits containing millions of ounces of gold (Milési et al., 2006). Examples include the Pala gold deposit in southwestern Chad (Tchameni et al., 2013) and the Batouri, Bétaré Oya, Ngoura, and Colomine gold deposits in the eastern region of Cameroon (Vishiti et al., 2017 and references therein). In Cameroon, the CASZ is represented by the Central Cameroon Shear Zone (CCSZ; Fig. 1a, b) and is oriented NESW with its related features (Sanaga Fault and the Tcholliré-Banyo Faults) (Penaye et al., 2006).

Studies related to primary gold mineralization in the eastern region of Cameroon are limited to the Batouri and Bétaré Oya gold districts (Suh et al., 2006; Asaah et al., 2014; Ateh et al., 2017; Vishiti et al., 2017,2019 , and references therein). Gold mineralization in these districts is spatially associated with sulphide minerals such as pyrite and arsenopyrite (Suh et al., 2006; Vishiti, 2017) in quartz veins within metamorphosed volcano-sedimentary sequences and altered granitic wall-rock. Silicification, sulphidation, sericitization, haematitization, and carbonatization are described as the main alteration processes. Fluid inclusion data from Batouri suggests moderately saline brine as ore-bearing fluid and mesothermal conditions of ore deposition consistent with the magmatic source of gold (Vishiti et al., 2019). The $\delta^{34} \mathrm{~S}$ values for this system reflect a single homogenous and generally light source of sulphur. The granitoid intrusions in the area include syn- to post-collisional I-type granites and show characteristics of intrusion-related gold deposits formed under reducing conditions (Asaah et al., 2014; Ateh et al., 2017; Tata et al., 2018).

Few contributions to a better understanding of gold mineralization in Cameroon have been reported from the Colomine area (located north of Batouri and south of Bétaré Oya), despite the increasing interest of SMEs with local investors content in this area. This area comprises several small alluvial mining sites in the vicinity of granitic 


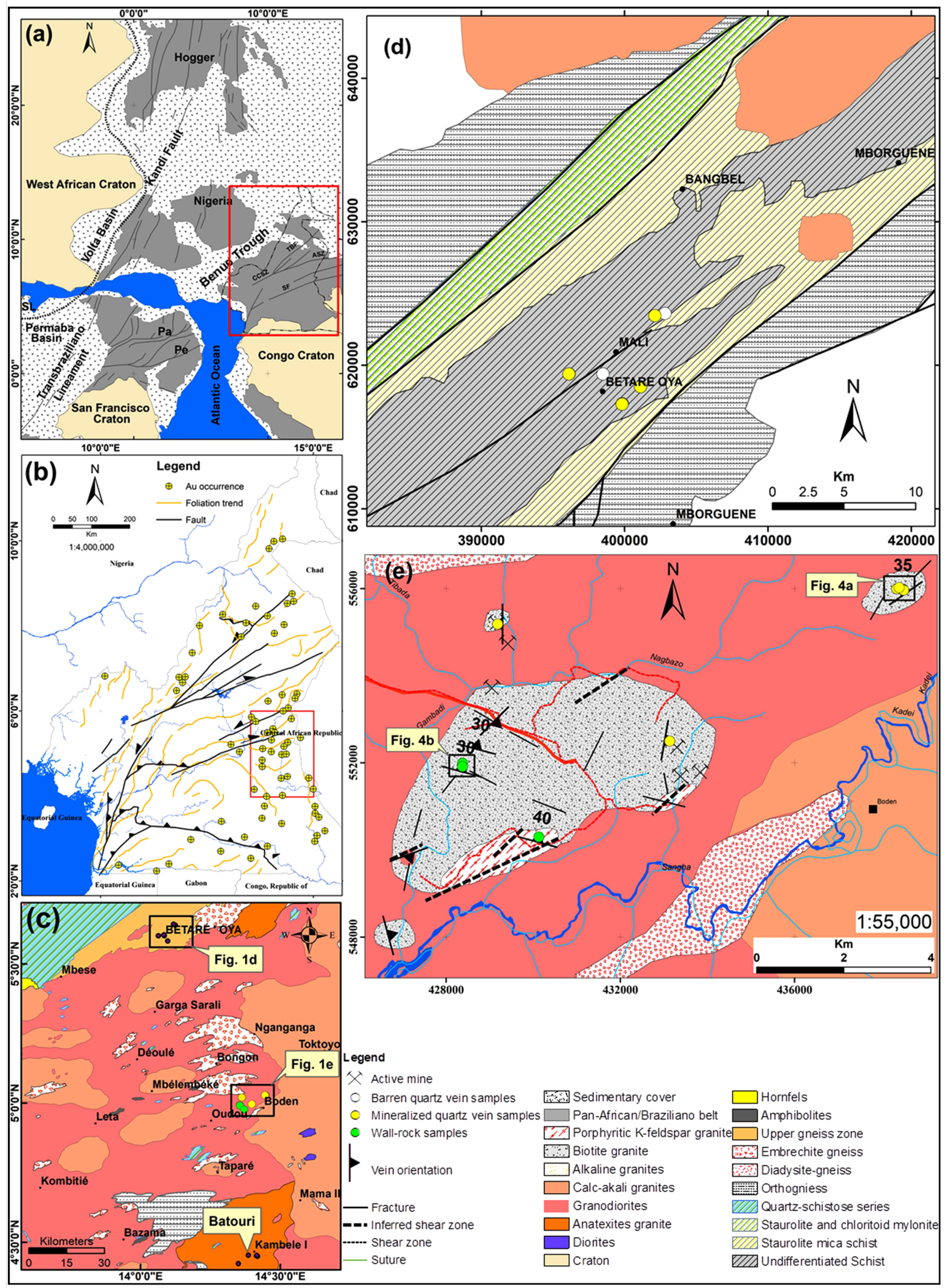

Figure 1. (a) Pre-drift reconstruction of the Pan-African/Braziliano Shear and Thrust Belt between the São Francisco, Congo, and West African Cratons. (b) Map of Cameroon showing the distribution of Au occurrences. Note the concentration of gold in the eastern region of Cameroon (red rectangle not to scale). (c) Geological map of Batouri east sheet No. NB 33 S.W. E.31 with an inset of the study areas (black rectangles; modified from Gazel and Gérard, 1954). (d) Geology and sampling points of quartz veins in the Bétaré Oya gold district. (e) Geology and sampling points of quartz veins and contact granite in the Colomine gold district. CCSZ =Central Cameroon Shear Zone; CVL =Cameroon volcanic line; KF = Kandi Fault; Pa = Patos Shear Zone; Pe=Pernambuco Shear Zone; SF =Sanaga Fault; TBF=Tcholliré-Banyo Fault. 
plutons currently exploited by artisanal miners and semi-mechanized mining companies (e.g., Lu and Lang Mining, Peace Mining \& Hong Kong Mining). The gold reserve in the Colomine gold district was estimated at about $12 \mathrm{t}$ in 2006 (Milési et al., 2006). In open pits, alluvial gold content varies from 0.1 to $4.6 \mathrm{~g} / \mathrm{m}^{3}$ (Takodjou Wambo et al., 2018). Fuh (1990) described gold mineralization in the district as related to NE-SW-trending quartz veins along shear zones hosting Itype granitoids transacted by pegmatitic veins. The nature and mineralogy of the auriferous veins and wall-rock alteration zone (s) remain poorly constrained, hence the genesis and evolution of the mineralizing fluid are still enigmatic. Prospective E-W, NW-SE, and N-S mineralization channels have also been outlined by remote sensing work in parts of this gold district (Gouet et al., 2013; Takodjou Wambo et al., 2016) and require further investigation. Takodjou Wambo et al. (2018), using a combined ordinary kriging model (OK) and GIS analysis of alluvial open-pit samples, delineated the villages of Colomine, Woumbou, Tassongo, Madubal, and Boutou as the most prospective localities for primary gold exploration. These locations provide an opportunity to investigate the alteration mineralogical assemblages of auriferous quartz veins and wall-rock alteration zones. Two hypogene stages of gold mineralization of metamorphic with possible mantle and/or magmatic contributions are proposed for the source of the mineralizing fluids in the gold district (Ndonfack et al., 2021): a gold-bismuthinite-tellurobismuthitesulfide (stage 1) consisting of low salinity aqueous-carbonic fluids with trapping temperatures of $\sim 300^{\circ} \mathrm{C}$ and a gold-hematite-tellurobismuthite-sulfide (stage 2) consisting of aqueous fluid inclusions with trapping temperatures between 205 and $245^{\circ} \mathrm{C}$. These stages were overprinted by a supergene mineral assemblage comprising greenockitehematite-limonite-goethite. Little is still known about the relative timing of these mineralization events.

According to Khant et al. (2012), different alteration mineral assemblages may occur with distance from the mineralization outward across the vein to the host rock, showing the progression of actions and modification of the fluid as it moves into or away from the vein. Using optical satellite imagery (Landsat-8 and ASTER) in a GIS platform, Takodjou Wambo et al. (2020) attempted to spatially associate lineaments and known locations of gold mineralization with mapped hydrothermal alteration zones of iron oxide/hydroxide, clay, carbonate, and silica. A detailed study of the alterations and geochemistry of the veins associated with the gold has yet to be undertaken. An understanding of the fluid chemistry and specific alterations associated with or responsible for gold mineralization has been obtained from geochemical characteristics of quartz veins of several deposits (Deksissa and Koeberl, 2004; Sarangi et al., 2013; Kalliomäki et al., 2017). Therefore, the study of mineralogy and geochemistry of quartz veins and host rocks in the Colomine area can help to clarify the genesis and evolution of mineralizing fluids and develop a comprehensive model for gold mineralization in eastern Cameroon.

The present work addresses the mineralogy and alteration relations of the quartz veins and wall-rock in the Colomine gold district and discusses the geochemical distribution of gold and associated elements in the mineralized zone to reveal geochemical associations and the genesis of the mineralizing fluids and timing. Although the Bétaré Oya gold district is well documented, new mining sites continue to be discovered and the need for further research becomes apparent. With this in mind, quartz vein samples from some of these new mining sites in the
Bétaré Oya gold district were collected and analysed during a field campaign to better document gold mineralization in the eastern region of Cameroon. The schistose wall-rocks in the district are highly weathered over a depth of several metres and were not sampled. These data are part of a wider scheme to increase the participation of local SMEs in gold mining in Cameroon through capacity building by the University of Buea.

\section{Geological Setting}

The Colomine gold district is located north of Batouri and south of the Bétaré Oya gold districts in the eastern region of Cameroon. These gold districts all belong to the Adamawa-Yade lithostructural domain (AYD) of the Pan-African Central African Fold Belt (CAFB), north of the Congo Craton (Toteu et al., 2004, 2006; Fig. 1c). The main rock types of the AYD include orthogneiss, metasedimentary and meta-volcaniclastic rocks, and syn- to late-tectonic granitoids (Toteu et al., 2004; Van Schmus et al., 2008). The evolution of the CAFB is attributed to the convergence and collision of the São Francisco-Congo and the West African Cratons (Castaing et al., 1994; de Wit et al., 2008). In the course of the orogeny, major deformational zones originated all across the belt (Borborema province of NE Brazil, Hoggar, Nigeria, and Central Africa) as strike-slip tectonics, trans-tensional, and transpressional episodes. The Central African Shear Zone (CASZ) is one of such major shear zones which extends into Cameroon, where is known as the Central Cameroon Shear Zone (CCSZ) (Castaing et al., 1994; Njome and Suh, 2005).

Three major tectonic events resulting in four deformation phases (D1-D4) have been documented in the Pan-African Neoproterozoic fold belt of Cameroon (Toteu et al., 2004; Li et al., 2017). The first compressional deformation event, D1, resulted in early Pan-African crustal thickening, plutonism, regional metamorphism, and nappe tectonics. In the Bétaré Oya gold district (Fig. 1d), D1 resulted in flat-lying (horizontal) foliation characterised by metamorphic banding. D2 overprinted D1, superimposing S2 schistosity with NE-SW strike in low-grade metasedimentary and volcanoclastic schist units on S1 foliation (S1/S2; Kankeu et al., 2009). The schist units (biotite schists, sericite, and chlorite schists) locally host NE-SW-trending gold-bearing quartz veins (Vishiti et al., 2017). They are intruded by post-tectonic mafic and felsic granitoids dated at ca. $635 \mathrm{Ma}$ (Ateh et al., 2017). After D2, there was a ductile ENE-WSW striking strike-slip shearing (D3) event that was geometrically related to the NE-SW striking BétaréOya shear zone (BOSZ) and the Sanaga shear zone (SSZ) (Fig. 1a). $\mathrm{N}-\mathrm{S}$ to NW-SE trending, sub-vertical, predominantly dextral, but also sinistral strike-slip faults cut through the $\mathrm{S} 1 / \mathrm{S} 2$ foliation and the ductile D3 shear zone structures. The shearing (D3) is inferred to have led to the generation of mylonites in the granitoids (Kankeu et al., 2009). The mylonitized granitoids were not identified in the investigated sites of the current study.

In the Colomine gold district, D1 and D2 are also reported (Fuh, 1990), but their detailed structural characteristics are still not available. The host rocks to the gold mineralization are clearly different from those reported in the Bétaré Oya gold district. Gold here is confined to $\mathrm{NE}-\mathrm{SW}$-trending quartz veins along zones of shearing and pegmatitic veining that transect pre- to syn-tectonic granite plutons (Fuh, 1990; 
Ngatcha et al., 2019; Takodjou Wambo et al., 2020). The granite plutons are dominantly biotite and porphyritic K-feldspar-rich (Fig. 1e). Hydrothermal whitish quartz veins and veinlets (millimetre to centimetre thick) are common within them, some of which contain whitish plagioclase $\pm \mathrm{K}$-feldspar and are chloritized. The granites generally become brecciated, sheared, foliated, and sericitized at the contact
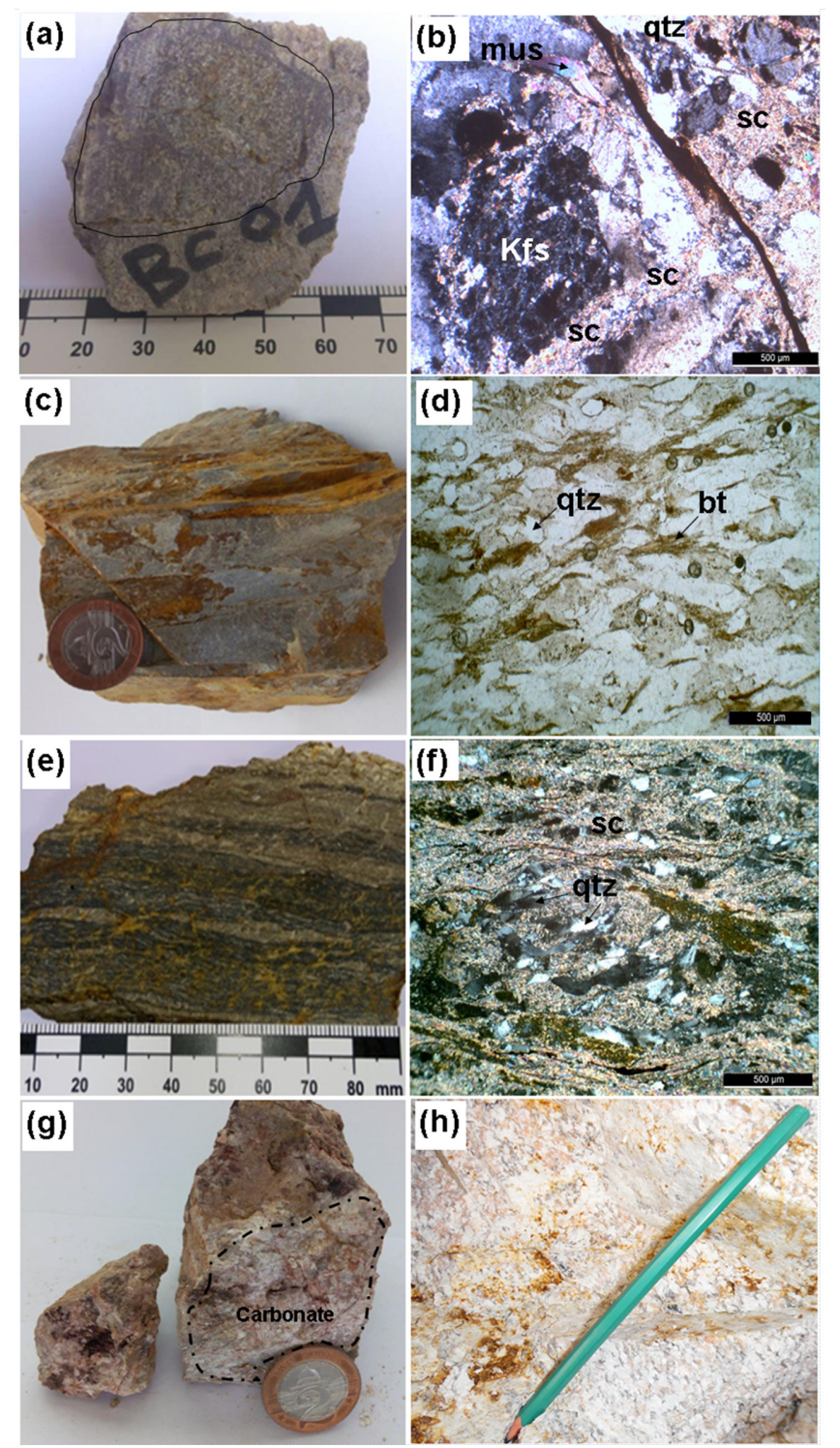

Figure 2. Macro photos and photomicrographs of altered contact granites showing various alteration types in the Colomine gold district. (a) Delineate K-feldspar porphyroclast in wall-rock sample. (b) Polished section showing partly sericitized K-feldspar surrounded by a sericite-muscovite-rich matrix (XPL). Note the Feoxide-filled fracture. (c) Slightly foliated fractured wall-rock. (d) Polished section showing the S-C fabric (PPL). Incipient development of solid-state foliation is marked by oriented recrystallization of biotite trails in the quartz-feldspar-mica matrix. (e) Strongly foliated wall-rock with millimetre-thick quartz veins. Quartz veins are parallel to the foliation. (f) Polished section showing ductile deformation in the mylonitized granite. (g) Vuggy filled hematite in wall-rock with carbonate alteration. (h) kaolinated pink granite. $K f s=K$-feldspar, $b t=$ biotite, mus $=$ muscovite, $s c=$ sericite, $q t z=$ quartz. The 2 Naira coin is $2.5 \mathrm{~cm}$ in diameter. with schist units that have now weathered into saprolitic material. These hydrothermally altered contact granites are hereafter also referred to as wall-rock and occur in micro-shear and fault zones. They are characterised by pervasive hydrothermal alterations with which gold is associated with concentrations of up to $32 \mathrm{ppb}$. These wall-rocks are considered significant for understanding gold mineralization in the area. They are further described in this paper to better elucidate their characteristics.

\section{Petrology of Altered Contact Granite (Wall-Rock)}

Contact granites are medium- to coarse-grained and composed of quartz $(35 \%)$, feldspar ( $50 \%$; dominated by K-feldspar), biotite $(10 \%)$, and sulphide minerals $(1 \%)$. Their structure varies from massivebrecciated to sheared and foliated (Fig. 2a-e). K-feldspar porphyroclasts measure 5-25 $\mathrm{mm}$ in the massive-brecciated and sheared varieties and are generally broken with their rims altered to sericite/muscovite (Fig. 2b). Both weakly and strongly foliated wall-rocks are present in the area. The weakly foliation type (Fig. 2c) is defined by the alignment of millimetric (mm) long mica-rich bands alternating with quartz-feldsparrich bands (Fig. 2d). The strongly foliated (mylonitized, Fig. 1e) type is characterised by S-C fabric, and strained biotite flakes alternating with quartz-sericite-rich domains (Fig. 2f). Quartz in the wall-rock samples is usually deformed into lenses, and pinch and swell structures in the hand specimen. Brecciated (augen shape) and recrystallized quartz grains with undulatory extinction are also common. Schist stringers are also occasionally present.

These micro-shear and fault zone granites are characterised by phylliclike alteration; sericite-muscovite + chlorite + albite + quartz. Sericitemuscovite (hydrothermal alteration minerals) appears both as a replacement of the primary minerals and as fillings in vesicles, vugs, and fractures. Sericitization is the dominant alteration type here. Sericite/muscovite and recrystallized quartz dominate the matrix. Monazite, zircon, ilmenite, rutile, and tourmaline are common secondary minerals in biotite flakes. Rutile and tourmaline occur mainly along cleavage planes in biotite. Oxidation is common along fractures and around brecciated to sheared quartz grains (Fig. 2b). Carbonatization and kaolinization are sometimes associated with the wall-rock (Fig. 2g-h).

\section{Sampling and Analytical Methods}

The Colomine and Bétaré Oya gold districts are characterised by a thick overburden of deep lateritic soils. However, quartz veins are exposed in abundant exploration pits/trenches exploited by artisanal and semi-mechanized mining activities (Fig. 3). These veins have been systematically described, categorized, and sampled. The trenches expose outcrops of both mineralized and non-mineralized quartz veins. Six representative mineralized quartz vein samples were collected and analysed in the Colomine gold district. The edges of granitic rocks at the contact with host rocks, presented by Ngatcha et al. (2019), are also discussed in relation to these quartz veins. In the Bétaré Oya gold district, where more quartz vein exposures were observed, eight mineralized vein samples were collected and analysed.

Polished sections of ten mineralized quartz vein samples from both gold districts were prepared for petrographic studies at the University 

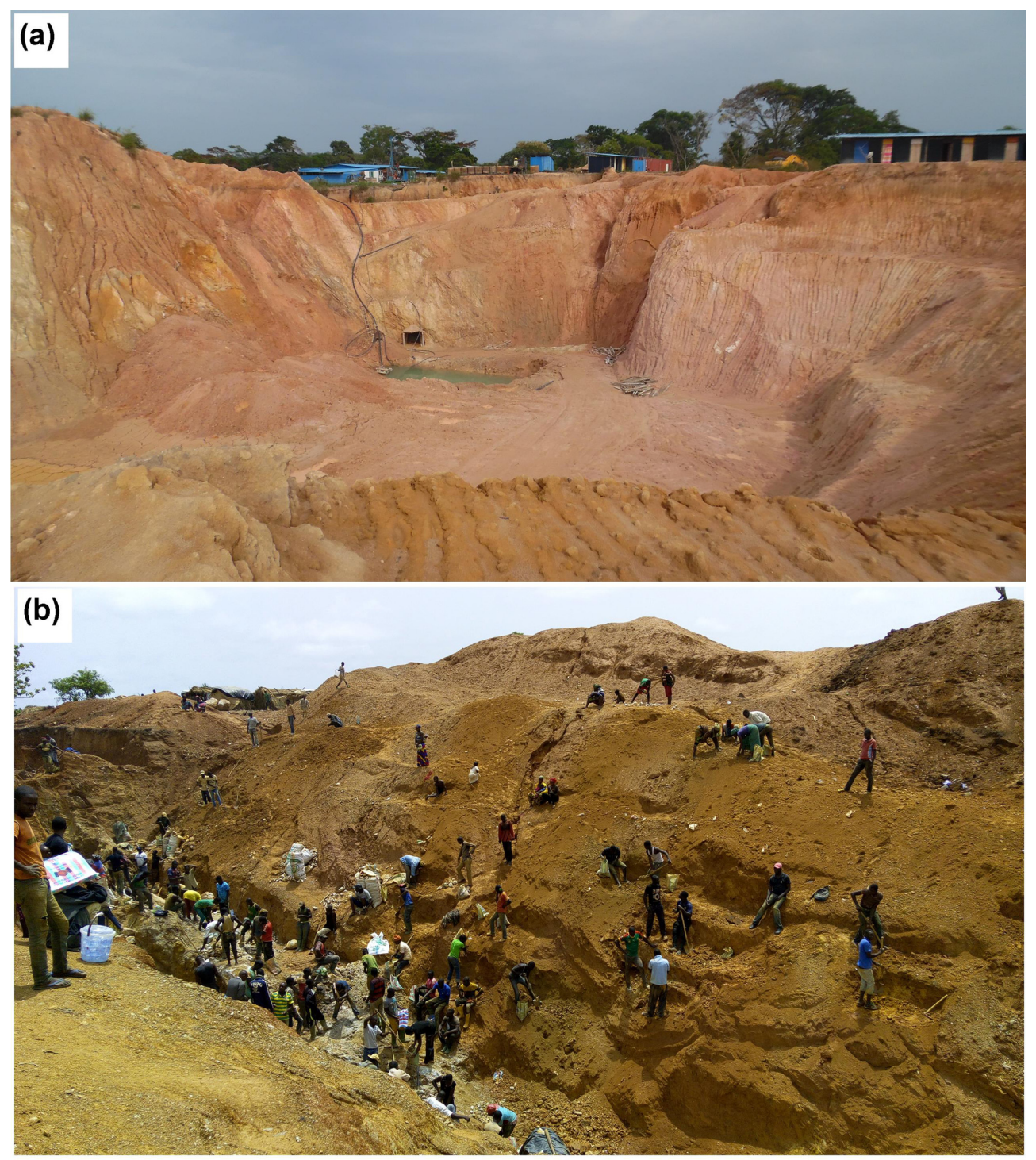

Figure 3. Field photographs of (a) an open pit about $30 \mathrm{~m}$ deep from a semi-mechanized mining site at Boutou in the Colomine gold district (b) a hand-dug trench at Dokolo in the Bétaré Oya area. The exposed giant quartz vein is $6 \mathrm{~m}$ wide and extends for $50 \mathrm{~m}$ and is still being worked by miners. It is hosted by weathered schist, $N 60^{\circ} \mathrm{E}$. The depth varies between $8-14 \mathrm{~m}$.

of Johannesburg, South Africa. These polished sections were then examined at the Department of Geology, University of Johannesburg, South Africa, using a LEICA DMLP microscope.

Polished thin sections were coated with carbon before scanning electron microscope (SEM) analysis. Backscattered electron (BSE) images were acquired using a fully automated VEGA3 TESCAN microscope at the University of Johannesburg, South Africa. A simultaneous investigation of the chemical composition of fine inclusions and other mineral constituents was carried out semi-qualitatively with an energy dispersive spectrometer (EDS) using an Oxford system attached to the SEM. An accelerating voltage of $20 \mathrm{kV}$ and a working distance of $15 \mathrm{~mm}$ were used in the analysis.

The geochemical analyses of trace elements from the fourteen mineralized quartz vein samples from the Colomine and Bétaré Oya gold districts were carried out by a combination of instrumental neutron activation analysis (INAA) and inductively coupled plasma mass spectrometry (ICP-MS) at Activation Laboratories Ltd. Ontario, Canada, using the Ultratrace $5(\mathrm{Au}+59$ elements) analytical package. Sample digestion involved both total dissolved and multi-acid attacks (hydrochloric, nitric, perchloric, and hydrofluoric acids). ICP-MS analyses by multi-acid digestions, while INAA provides total metals. Detection limits and quality assurance indicators are available at www.actlabs.com.

\section{Results}

\section{Quartz Veins Characteristics}

\section{Colomine gold district}

Primary gold mineralization in this area is mainly associated with fracture-filled quartz veins hosted by granitoids (Fig. 4a) and rarely along cleavage planes in schist now weathered to saprolitic material 

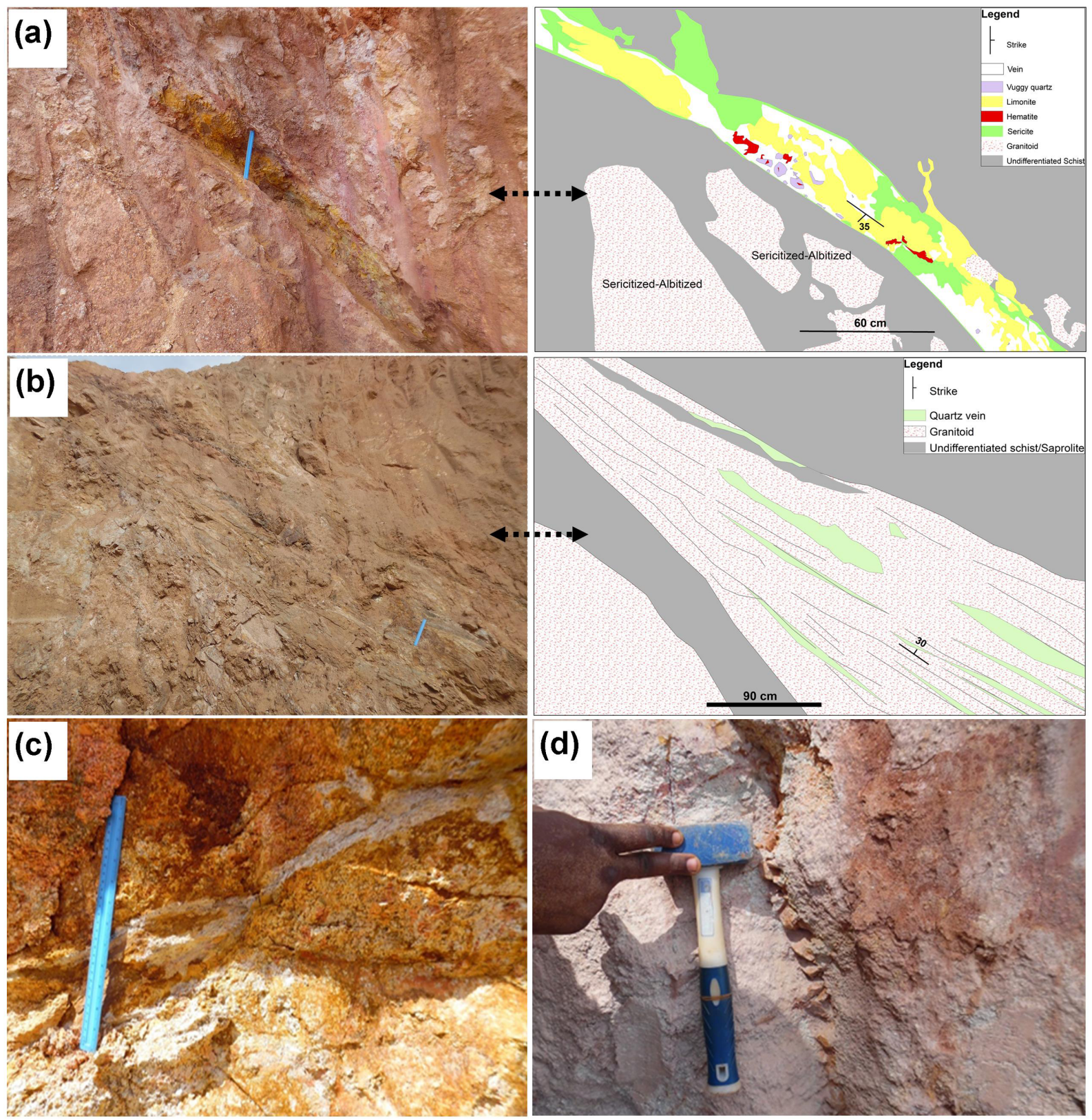

Figure 4. Structural disposition and schematic representation of the Colomine quartz veins (a) Detail of the internal structure of the altered NNE-SSW mineralized quartz vein in the village of Garoua. (b) Detail internal structure of NW-SE milimetric to centimetric non-mineralized quartz veins at Konkai. Field photos of vein samples show (c) pinch and swell structures in granitoid at Trou du Roi and (d) $N-S$ trending whitish non-mineralized quartz vein crosscutting weathered, strongly albitized granitoid at Garoua village. The hammer is $30 \mathrm{~cm}$ long.

(Fig. 4b). Mineralized (Fig. 4a) and non-mineralized (Fig. 4c-d) quartz veins were encountered, with both categories displaying variable textural features. The orientation of quartz veins in the Colomine gold district varies widely from N-S, NNE-SSW, and NE-SW with a gentle dip to the NW $\left(35^{\circ}\right)$ as identified in the villages of Tassongo, Mt. Kaleka, and Garoua, and E-W to WNW-ESE, with a gentle dip $\left(30^{\circ}\right.$ to $40^{\circ}$ ) in other parts of the district. These quartz veins also show pinch and swell structures (Fig. 4c). The veins are massive (Fig. 5a, b), vuggy (Fig. 5c-e), fractured, and sheared to brecciated (Fig. 5f). They are continuous to discontinuous, 0.1 to $0.6 \mathrm{~m}$ thick, and vary in length from 0.1 to $2 \mathrm{~m}$. Elongated tabular clasts of the mica-rich schistose wallrock are present in some quartz vein samples as selvages/stringers.
The mineralized quartz veins are composed predominantly of quartz \pm gold \pm sulphide \pm carbonate and secondary minerals like hematite and limonite. Fe-oxides commonly fill the fractures. On the other hand, the non-mineralized veins consist of massive quartz and limonite stains filling the fractures (Fig. 5a). Quartz varies in colour from white to creamy white and sometimes smoky (Fig. 5b). Vugs within the quartz veins vary in size from 2 to $10 \mathrm{~mm}$ and are usually empty or filled with Fe-oxides (limonite and/or goethite). Limonite also coats the surfaces of fractured, sheared, brecciated quartz samples and wall-rock edges. Sulphide generally occurs as inclusions in smoky quartz, predominantly along fractured surfaces, but not within the vein (cut surface). Carbonate is also generally associated with mineralized veins. 

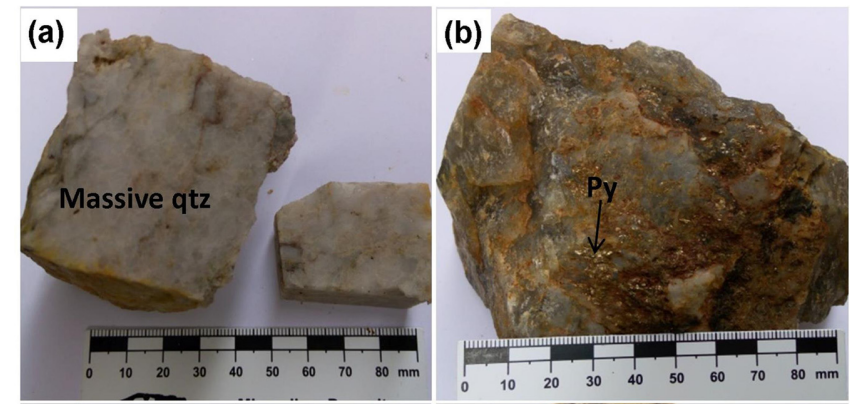

(c)
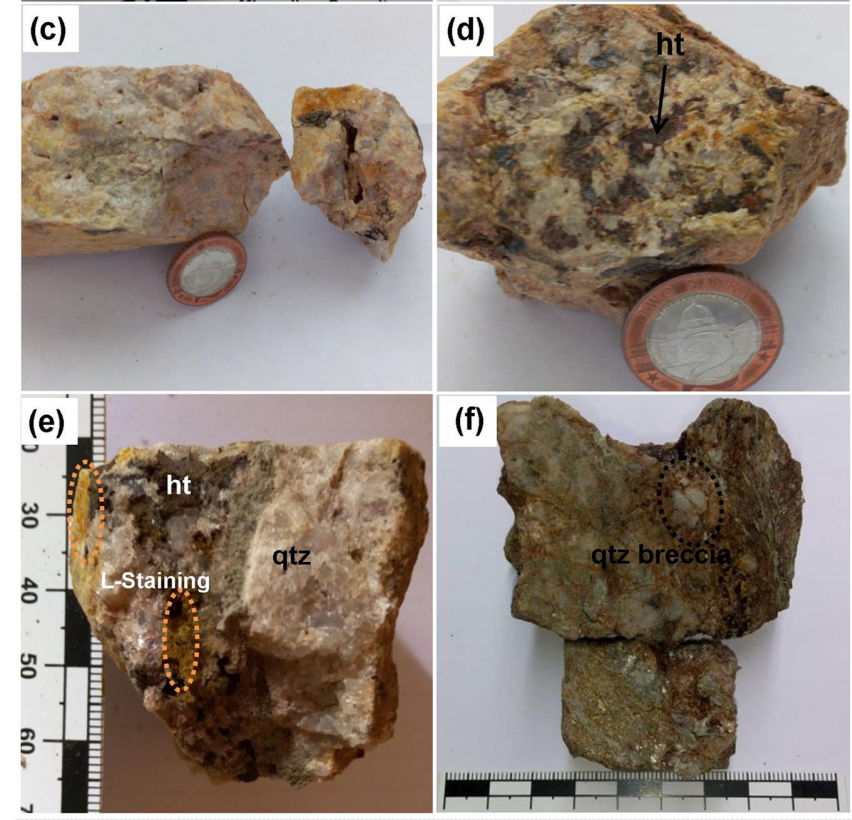

Figure 5. Hand specimens showing various alteration types in the Colomine gold district. (a) Whitish quartz with limonite stains along the fractures. (b) Pyrite inclusion in quartz. (c-d) Hematite-filling vugs in quartz. (e) Limonite staining on quartz and hematite. (f) Quartz breccias. $q t z=q u a r t z, P y=$ pyrite, $h t=$ hematite, $L=$ limonite. The 2 Naira coin is $2.5 \mathrm{~cm}$ in diameter.

In polished sections, quartz occurs as euhedral, sutured, and elongated crystals exhibiting undulatory extinction (Fig. 6a). Most crystals are traversed by sub-parallel, trans-granular microfractures filled with hydrothermal quartz and sericite and interspersed with secondary fluid inclusion trails. The margins and interstitial spaces within these micro-veins are generally rich in Fe-oxides. Sometimes, relics of pyrite crystals are observed, which are easily replaced by crystalline hematite. Botryoidal hematite is also common and is characterised by a lumpy or reniform appearance (Fig. 6b, c). These relics show distinct rims rich in hematite $(59.1 \mathrm{wt} \% \mathrm{Fe})$, limonite, and goethite (Fig. $6 \mathrm{c}, \mathrm{d})$. Hematite, limonite \pm goethite are the main weathering-related minerals. A few selvages of wall-rock along the quartz veins bear $\mathrm{K}$ feldspar, plagioclase, sericite, biotite, and muscovite.

\section{Bétaré Oya gold district}

The quartz veins in this area are mainly hosted by weathered schist units (Fig. 7). The weathered schists generally have an $\mathrm{N} 60^{\circ} \mathrm{E}$ orientation, with a moderate $\operatorname{dip}\left(55^{\circ}\right)$ to the SE. Two major trends in the quartz veins could be deciphered in the field. A general N60 $\mathrm{E}$ (at Dokolo)

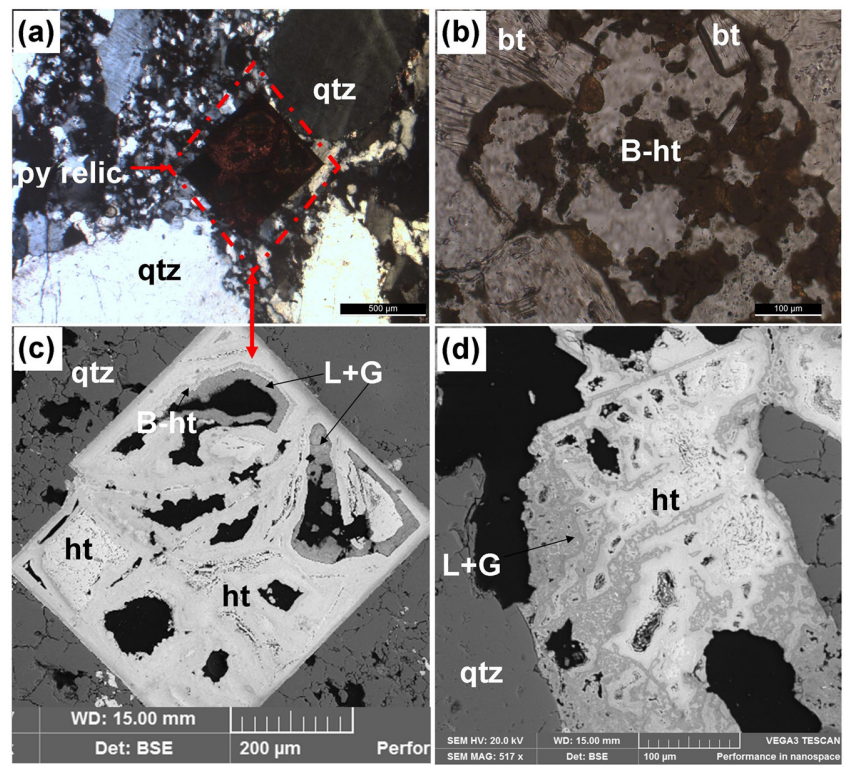

Figure 6. Photomicrographs of quartz vein samples from the Colomine gold district. (a) Brecciated quartz sample hosting pyrite relic, now replaced by crystalline hematite (in the centre of the section) (XPL). (b) Quartz sample with botryoidal hematite (XPL). (c) The BSE image of the pyrite relic shows euhedral crystalline hematite pseudomorph (after magnetite); $L+G=$ limonite and goethite due to weathering; (d) is a zoom photo of (c); B-ht = Botryoidally layered (colloidal) hematite (supergene stage). py $=$ pyrite, qtz $=q u a r t z, b t$ $=$ pyrite, $\boldsymbol{h t}=$ hematite, $B-h t=$ botryoidal hematite, $L+G=$ limonitegoethite. The 2 Naira coin is $2.5 \mathrm{~cm}$ in diameter.

to $\mathrm{N} 64^{\circ} \mathrm{E}$ (in Mbal North) trend (NE) parallel to the cleavage planes of the host schist (Fig. 7a-d) and a NW-SE to N-S orientation perpendicular to the host schistosity were also observed (Fig. 7e). A few veins with a distorted orientation of $\mathrm{N} 55^{\circ} \mathrm{E}, 60 \mathrm{SE}$ still parallel to the host schistosity were equally observed. The NE-trending veins are generally massive (Fig. 7f), fractured/brecciated to sheared (Fig. 7g), foliated (sheets stacked together) (Fig. 7h), and vuggy (Fig. 7i-j), and contain mostly milky, smoky, and sugary quartz. Stockworks are also evident in these veins from hand samples (Fig. 7f). In contrast, the NW-SE to $\mathrm{N}-\mathrm{S}$ trending veins are generally massive and foliated with whitish/ milky quartz. The thickness of the veins in both categories ranges from centimetres to metres and can be up to $6 \mathrm{~m}$.

Mineralogically, the NE-trending veins consist of quartz, sericite, pyrite \pm gold, carbonate, hematite, and limonite-goethite. Silicification, sulphidation, sericitization, hematitization, and carbonatization characterise these veins. Hematitization dominates in the vuggy quartz veins (Fig. 7i-j). These vugs occasionally contain dark spots, probably rich in oxides. The NW-SE to N-S trending veins contain only quartz stained by limonite. In thin sections (Fig. 8), relics of pyrite show sieve textures that host goethite and possibly gold. Limonite-goethite commonly fills the interstitial spaces between quartz crystals.

\section{Whole-Rock Geochemistry}

\section{Colomine gold district}

Table 1 shows the whole-rock geochemical analysis of trace ele- 

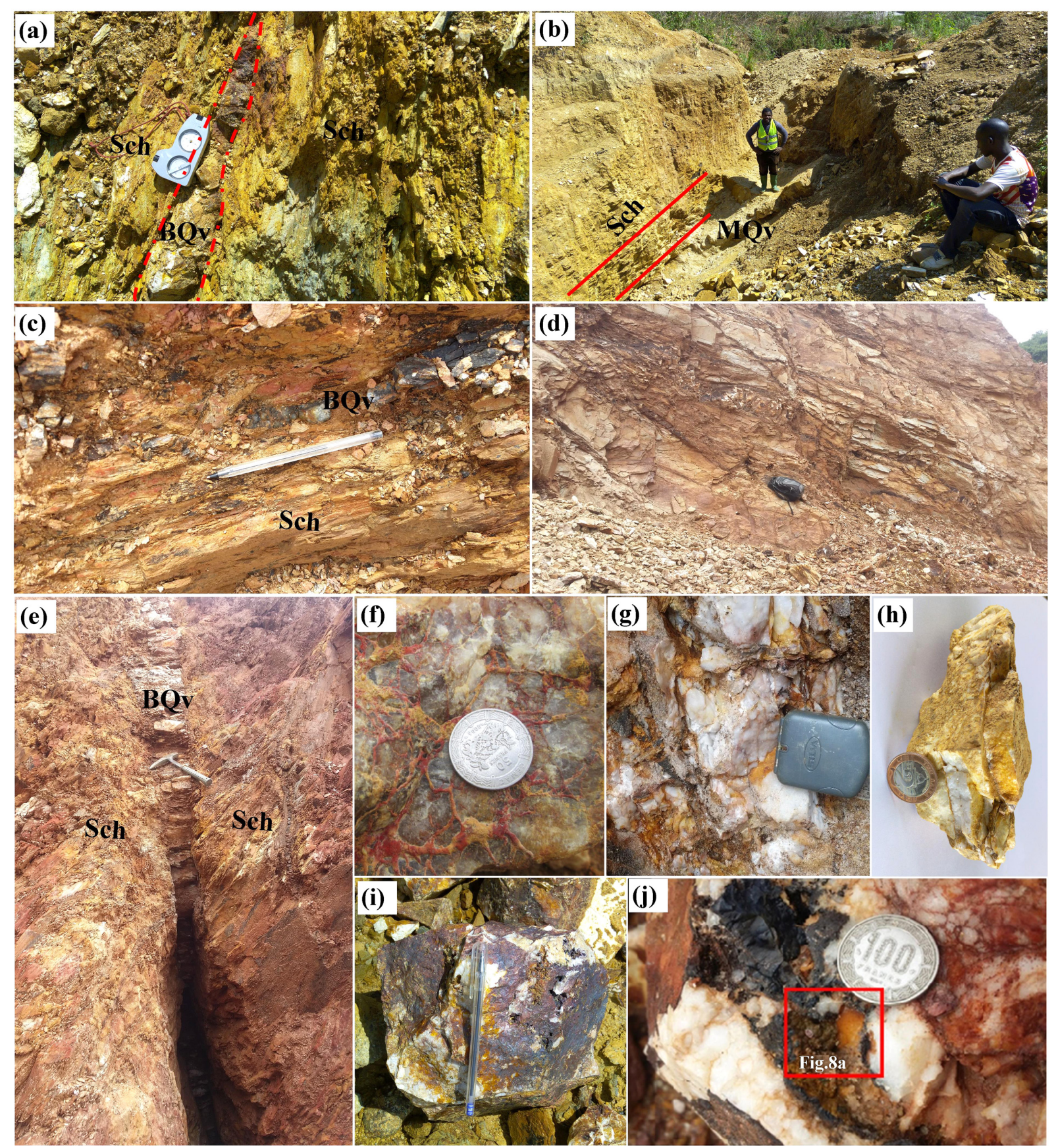

Figure 7. Field photographs and hand specimens in the Bétaré Oya gold district. (a) Quartz vein and veinlets along schistose planes in weathered host schist at Mbal North. The sericite alteration is represented by the yellowish colour. (b) Exposed vein parallel to cleavage planes in schist. (c-d) Smoky quartz veins parallel to the weathered schist host rock at Longa Mali. (e) $N-S$ trending quartz vein cross-cutting schistose planes at Longa Mali. (f) Smoky quartz with stockwork veins. (g) Limonite-goethite filling in the fractured vein. (h) Foliated milky-white quartz vein sample stained by limonite. (i-j) Strongly hematitized, vuggy quartz samples. Sch $=$ schist, BQv = Barren Quartz vein, MQv $=$ Mineralized Quartz vein.

ments from quartz veins in the Colomine gold district. Fe $0.9-5.42$ $\mathrm{wt} \%, \mathrm{Mg} 0.01-0.19 \mathrm{wt} \%$, Na 0.08-2.61 wt \%, K 0.22-2.16 wt \%, and $\mathrm{Ca} 0.04-1.22 \mathrm{wt} \%$ are among the elements found in quartz veins. In ppm, there are significant levels of Ag (0.06-0.29), As (1.3-4.7), Ba (51-826), $\mathrm{Bi}(0.12-0.85), \mathrm{Cr}$ (22-97), Cu (17.6-48.3), Mn (44-2190), $\mathrm{Mo}$ (0.07-16.9), Pb (15.8-133), Rb (10.6-85.2), Sb (0.6-1.5), Sr (11-521), $\mathrm{V}$ (20-115), and Zn (1.9-133). Gold concentrations vary between 3 and $2070 \mathrm{ppb}$. Mineralized veins have an Au content higher than the average concentration in the Earth's crust. Samples BC18 and BC19 have 2070 and $1420 \mathrm{ppb} \mathrm{Au}$, respectively. The $\mathrm{Au} / \mathrm{Ag}$ ratio varies from $0.0-12.2 \mathrm{ppb}$. It is noteworthy that the silver and arsenic content are generally low, while the contents of $\mathrm{Cu}, \mathrm{Pb}, \mathrm{Mn}, \mathrm{Zn}$, and $\mathrm{Ba}$ are locally enriched. Tellurium (Te) concentrations are also generally lower $(0.1-0.5)$ with some below detection limits. Tantalum $(\mathrm{Ta})$ and tungsten $(\mathrm{W})$ values are below the detection limit for all the quartz veins. Besides $\mathrm{Au}-\mathrm{Ag}$, $\mathrm{Au}-\mathrm{Mo}, \mathrm{Ba}-\mathrm{Sr}, \mathrm{As}-\mathrm{Sb}$, and $\mathrm{Pb}-\mathrm{Sb}$, which show 
Table 1. Trace and REE composition of quartz veins samples

\begin{tabular}{|c|c|c|c|c|c|c|c|c|c|c|c|c|c|c|c|}
\hline & \multicolumn{8}{|c|}{ Colomine } & \multicolumn{7}{|c|}{ Bétaré Oya } \\
\hline wt $\%$ & $\mathrm{DL}$ & BC11 & BC12 & BC16 & BC18 & BC19 & BC20 & BBO1 & $\mathrm{BBO} 2$ & $\mathrm{BBO} 3$ & BBO4 & BBO5 & BBO6 & BBO9 & BBO12 \\
\hline $\mathrm{Fe}$ & 0.01 & 1.57 & 2.72 & 5.42 & 0.93 & 0.9 & 4.22 & 1.37 & 1.07 & 1.15 & 3.82 & 1.04 & 1.49 & 1.52 & 1.16 \\
\hline $\mathrm{Na}$ & 0.01 & 2.61 & 1.64 & 0.32 & 0.08 & 0.08 & 0.42 & 1.36 & 0.09 & 2.93 & 0.57 & 0.11 & 3.38 & 3.56 & 0.03 \\
\hline $\mathrm{Mg}$ & 0.01 & 0.18 & 0.19 & 0.19 & 0.01 & 0.01 & 0.18 & 0.11 & 0.01 & 0.14 & 0.16 & 0.01 & 0.14 & 0.17 & 0.01 \\
\hline $\mathrm{K}$ & 0.01 & 2.16 & 1.71 & 1.23 & 0.22 & 0.22 & 0.65 & 1.74 & 0.21 & 3.11 & 1.49 & 0.25 & 2.79 & 2.99 & 0.12 \\
\hline $\mathrm{Ca}$ & 0.01 & 0.96 & 1.12 & 0.65 & 0.04 & 0.05 & 1.22 & 0.53 & 0.04 & 0.85 & 1.01 & 0.05 & 1.03 & 1.03 & 0.01 \\
\hline \multicolumn{16}{|l|}{ ppm } \\
\hline $\mathrm{Li}$ & 0.5 & 31.4 & 25.3 & 14.4 & 1 & 0.9 & 12.7 & 14.9 & 1 & 43.4 & 12.3 & 1 & 33.5 & 35.3 & 1 \\
\hline $\mathrm{Ba}$ & 1 & 732 & 675 & 826 & 52 & 51 & 294 & 452 & 42 & 651 & 749 & 52 & 781 & 804 & 23 \\
\hline $\mathrm{Be}$ & 0.1 & 3.8 & 2.6 & 1.8 & 0.3 & 0.3 & 1.1 & 2 & 0.3 & 5.1 & 1.1 & 0.3 & 4 & 4.1 & 0.3 \\
\hline $\mathrm{Bi}$ & 0.02 & 0.85 & 0.37 & 0.3 & 0.12 & 0.17 & 0.22 & 0.15 & 0.12 & 0.23 & 0.17 & 0.08 & 0.59 & 0.17 & 0.19 \\
\hline $\mathrm{Br}$ & 0.5 & bdl & 1.8 & 10.5 & bdl & bdl & 5.1 & bdl & bdl & bdl & 5.6 & bdl & bdl & bdl & bdl \\
\hline Cs & 0.05 & 5.39 & 3.68 & 3.14 & 0.35 & 0.1 & 1.82 & 2.48 & 0.12 & 35.7 & 1.56 & 0.1 & 5.4 & 5.71 & 0.38 \\
\hline $\mathrm{Sc}$ & 0.1 & 2.3 & 8.2 & 12 & 0.4 & 0.4 & 13.8 & 1.2 & 0.4 & 1.8 & 12.1 & 0.4 & 1.9 & 2 & 0.4 \\
\hline V & 1 & 20 & 63 & 59 & bdl & bdl & 115 & 7 & bdl & 11 & 67 & bdl & 15 & 16 & bdl \\
\hline $\mathrm{Cr}$ & 2 & 22 & 45 & 97 & 35 & 33 & 80 & 26 & 38 & 15 & 65 & 40 & 31 & 18 & 41 \\
\hline $\mathrm{Mn}$ & 1 & 212 & 489 & 2190 & 55 & 44 & 1030 & 99 & 51 & 117 & 844 & 49 & 123 & 130 & 53 \\
\hline $\mathrm{Co}$ & 0.1 & 3.3 & 11.7 & 64.3 & 0.9 & 0.9 & 20.8 & 1.8 & 0.9 & 2.5 & 18.7 & 0.8 & 2.5 & 2.6 & 1 \\
\hline $\mathrm{Ni}$ & 0.5 & 7.7 & 14.6 & 37 & 4.7 & 4.2 & 25.3 & 5.7 & 4.7 & 6.2 & 19.9 & 4.6 & 6.2 & 6.7 & 5.4 \\
\hline $\mathrm{Cu}$ & 0.2 & 17.6 & 24 & 45.6 & 33.3 & 29.9 & 48.3 & 25.4 & 25.8 & 8.2 & 32.4 & 33.3 & 8.8 & 10.7 & 17 \\
\hline $\mathrm{Pb}$ & 0.5 & 133 & 73.9 & 65.1 & 15.8 & 27.5 & 29.2 & 30.5 & 5.8 & 53.4 & 27.9 & 6.7 & 50.4 & 49.7 & 6.6 \\
\hline $\mathrm{Zn}$ & 0.5 & 43.7 & 56.6 & 133 & 1.9 & 2.1 & 111 & 14.9 & 1.1 & 32.9 & 61.4 & 1 & 35.9 & 38.5 & 1.2 \\
\hline $\mathrm{Ga}$ & 0.1 & 20.7 & 18.7 & 23.2 & 2.2 & 2.1 & 13.6 & 11.9 & 1.9 & 21.6 & 19.2 & 2.3 & 22.6 & 22.3 & 1.5 \\
\hline $\mathrm{Ge}$ & 0.1 & bdl & bdl & bdl & bdl & bdl & bdl & bdl & bdl & bdl & bdl & bdl & bdl & bdl & bdl \\
\hline $\mathrm{Rb}$ & 0.2 & 85.2 & 67.5 & 64.1 & 11.3 & 10.6 & 26.9 & 62.8 & 10.4 & 831 & 44.6 & 11.1 & 80.8 & 90.2 & 8.3 \\
\hline $\mathrm{Sr}$ & 0.2 & 521 & 403 & 121 & 12.2 & 11 & 195 & 269 & 10.1 & 542 & 211 & 11.5 & 549 & 557 & 3 \\
\hline $\mathrm{Y}$ & 0.1 & 5.8 & 11.6 & 20.9 & 2.7 & 2.3 & 14.4 & 4.2 & 2.2 & 3.3 & 15.4 & 2.5 & 3.4 & 3.4 & 1.6 \\
\hline $\mathrm{Zr}$ & 1 & 93 & 15 & 27 & 14 & 12 & 3 & 5 & 15 & 79 & 6 & 13 & 90 & 94 & 19 \\
\hline $\mathrm{Nb}$ & 0.1 & 2.3 & bdl & bdl & 1.1 & 0.9 & 0.2 & 1.6 & 1.2 & 1.5 & $<0.1$ & 1.3 & 1.3 & 1.8 & 1.2 \\
\hline Mo & 0.05 & 3.63 & 0.16 & 0.07 & 16.9 & 15.7 & 0.56 & 8.55 & 11.9 & 0.67 & 0.06 & 16.6 & 0.68 & 0.8 & 1.43 \\
\hline In & 0.1 & bdl & bdl & bdl & bdl & bdl & bdl & bdl & bdl & bdl & bdl & bdl & bdl & bdl & bdl \\
\hline $\mathrm{Sn}$ & 1 & 3 & bdl & 1 & 2 & 2 & bdl & 2 & 2 & 3 & bdl & 2 & 2 & 2 & 2 \\
\hline $\mathrm{Sb}$ & 0.1 & 1.5 & 0.9 & 0.8 & 0.6 & 0.7 & 0.6 & 0.4 & 0.4 & 0.7 & 0.4 & 0.4 & 0.3 & 0.1 & 0.6 \\
\hline $\mathrm{Te}$ & 0.1 & 0.5 & bdl & bdl & 0.1 & 0.2 & bdl & bdl & bdl & bdl & bdl & bdl & bdl & bdl & bdl \\
\hline $\mathrm{Cd}$ & 0.1 & 6.2 & 1.9 & 0.3 & 0.5 & 0.9 & 0.4 & 0.2 & bdl & 0.2 & 0.3 & bdl & 0.2 & bdl & 0.2 \\
\hline $\mathrm{Se}$ & 0.1 & 1 & 0.2 & bdl & 0.2 & 0.1 & 0.2 & bdl & bdl & bdl & bdl & bdl & bdl & bdl & bdl \\
\hline Hf & 1 & 4 & 10 & 24 & bdl & bdl & 7 & 2 & bdl & 3 & 22 & bdl & 3 & 3 & 2 \\
\hline $\mathrm{Ta}$ & 0.1 & bdl & bdl & bdl & bdl & bdl & bdl & bdl & bdl & 0.2 & bdl & bdl & bdl & bdl & bdl \\
\hline W & 1 & bdl & bdl & bdl & bdl & bdl & bdl & bdl & bdl & bdl & bdl & bdl & bdl & bdl & bdl \\
\hline $\mathrm{Re}$ & 0 & bdl & bdl & bdl & bdl & 0 & bdl & bdl & bdl & bdl & bdl & bdl & bdl & bdl & bdl \\
\hline $\mathrm{Ag}$ & 0.05 & 0.29 & 0.14 & 0.14 & 0.17 & 0.24 & 0.06 & 0.13 & 0.09 & bdl & 0.07 & 0.69 & bdl & bdl & bdl \\
\hline As & 0.5 & 4.7 & 3.5 & 3.2 & 1.3 & 2.4 & 2.3 & 1.6 & 0.8 & 0.7 & 2.8 & 1.3 & 1.1 & bdl & 0.8 \\
\hline $\mathrm{Tl}$ & 0.05 & 2.68 & 1.77 & 0.88 & 0.19 & 0.32 & 0.27 & 0.48 & bdl & 6.55 & 0.31 & bdl & 0.86 & 0.83 & 0.06 \\
\hline $\mathrm{Th}$ & 0.1 & 11.4 & 11.6 & 20.1 & 5.5 & 5.2 & 6.5 & 10.1 & 4.3 & 10.4 & 11.7 & 5.9 & 13 & 13.9 & 1.6 \\
\hline $\mathrm{U}$ & 0.1 & 4.7 & 4.2 & 3.9 & 0.7 & 0.6 & 1.9 & 4.2 & 0.6 & 4.1 & 2.5 & 1 & 4.6 & 5 & 0.5 \\
\hline $\mathrm{Au}(\mathrm{ppb})$ & 2 & 172 & 3 & 11 & 2070 & 1420 & bdl & 124 & 1250 & bdl & 4 & 4600 & bdl & 30 & 7 \\
\hline $\mathrm{Hg}(\mathrm{ppb})$ & 10 & 40 & 40 & 200 & 20 & 20 & 50 & 30 & 20 & 20 & 50 & 10 & bdl & 20 & 10 \\
\hline $\mathrm{Au} / \mathrm{Ag}$ & & 0.6 & 0.0 & 0.1 & 12.2 & 5.9 & - & 1.0 & 13.9 & - & 0.1 & 6.7 & - & - & - \\
\hline
\end{tabular}




\begin{tabular}{|c|c|c|c|c|c|c|c|c|c|c|c|c|c|c|c|}
\hline & \multicolumn{8}{|c|}{ Colomine } & \multicolumn{7}{|c|}{ Bétaré Oya } \\
\hline \multicolumn{16}{|c|}{ REE (ppm) } \\
\hline $\mathrm{La}$ & 0.1 & 23.5 & 25.6 & 44.8 & 11.4 & 10.5 & 21.8 & 18.3 & 9.1 & 15.9 & 29.8 & 11.1 & 17.3 & 17.8 & 6.8 \\
\hline $\mathrm{Ce}$ & 0.1 & 41.3 & 51.7 & 420 & 19.8 & 18.3 & 43.7 & 31.3 & 15.6 & 27.3 & 61 & 19 & 30.2 & 31.2 & 11.3 \\
\hline $\operatorname{Pr}$ & 0.1 & 5 & 5.3 & 11.6 & 2.2 & 2 & 4.6 & 3.6 & 1.7 & 3.3 & 6 & 2.1 & 3.6 & 3.7 & 1.3 \\
\hline $\mathrm{Nd}$ & 0.1 & 19.9 & 22.7 & 42.9 & 8.3 & 7.6 & 20.4 & 14.1 & 6.4 & 13.7 & 26.8 & 7.9 & 15 & 15.3 & 4.7 \\
\hline $\mathrm{Sm}$ & 0.1 & 3.3 & 4 & 7.5 & 1.3 & 1.1 & 3.8 & 2.4 & 1 & 2.3 & 5.1 & 1.2 & 2.4 & 2.4 & 0.8 \\
\hline $\mathrm{Eu}$ & 0.05 & 0.59 & 0.82 & 1.13 & 0.11 & 0.1 & 0.86 & 0.37 & 0.09 & 0.45 & 0.98 & 0.1 & 0.49 & 0.5 & 0.08 \\
\hline $\mathrm{Gd}$ & 0.1 & 2.3 & 3.3 & 7.5 & 1 & 0.9 & 3.7 & 1.6 & 0.8 & 1.4 & 4.4 & 1 & 1.5 & 1.7 & 0.6 \\
\hline $\mathrm{Tb}$ & 0.1 & 0.2 & 0.4 & 0.8 & 0.1 & bdl & 0.5 & 0.2 & bdl & 0.1 & 0.5 & 0.1 & 0.1 & 0.2 & bdl \\
\hline Dy & 0.1 & 1.2 & 2.3 & 4.3 & 0.6 & 0.5 & 2.8 & 0.9 & 0.5 & 0.7 & 3.2 & 0.6 & 0.8 & 0.8 & 0.3 \\
\hline Ho & 0.1 & 0.2 & 0.4 & 0.8 & bdl & bdl & 0.5 & 0.2 & bdl & 0.1 & 0.6 & $<0.1$ & 0.1 & 0.1 & bdl \\
\hline $\mathrm{Er}$ & 0.1 & 0.5 & 1.1 & 2 & 0.2 & 0.2 & 1.4 & 0.4 & 0.2 & 0.3 & 1.5 & 0.2 & 0.3 & 0.3 & 0.1 \\
\hline $\mathrm{Tm}$ & 0.1 & bdl & 0.2 & 0.3 & bdl & bdl & 0.2 & bdl & bdl & bdl & 0.2 & bdl & bdl & bdl & bdl \\
\hline $\mathrm{Yb}$ & 0.1 & 0.4 & 1 & 1.9 & 0.2 & 0.1 & 1.3 & 0.3 & 0.1 & 0.2 & 1.5 & 0.1 & 0.3 & 0.3 & 0.1 \\
\hline $\mathrm{Lu}$ & 0.1 & bdl & bdl & 0.3 & bdl & bdl & 0.2 & bdl & bdl & bdl & 0.2 & bdl & bdl & bdl & bdl \\
\hline
\end{tabular}

NB: DL (detection limit); bdl (below detection limit); ppm (part per million); ppb (parts per billion)
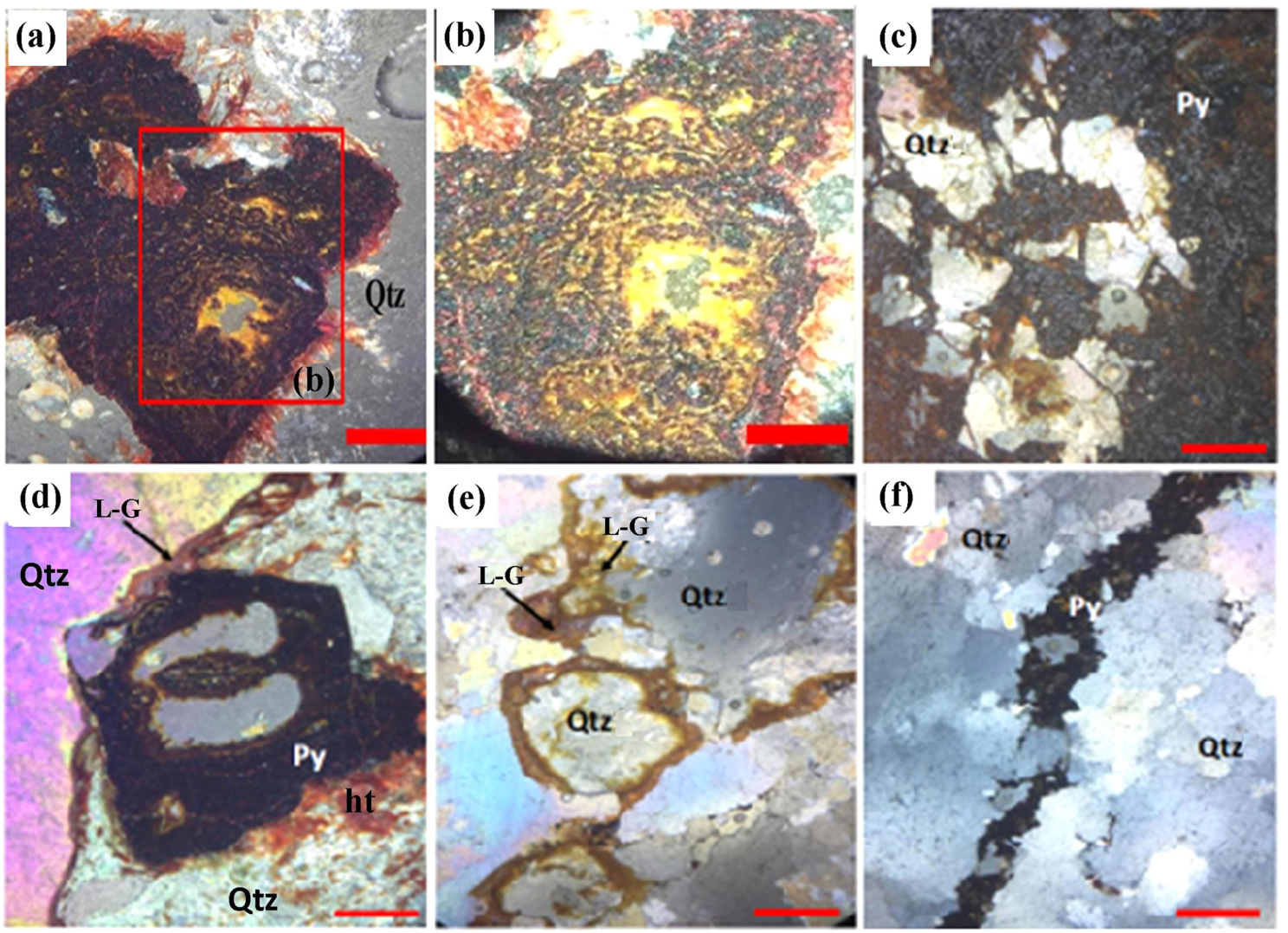

Figure 8. Photomicrographs of quartz samples from the Bétaré Oya gold district. (a-b) Sieve texture of strongly hematitized pyrite relic. The yellowish alterations in the centre of the pyrite relic are goethite. (c) Pyrite relic altered to hematite in a less advanced state compared to (a). (d) Brecciated pyrite and quartz microclasts. (e) Limonite-goethite alteration products along grain boundaries in quartz crystal. (f) Sulphide filling in micro veinlets in quartz. $Q t z=$ quartz, $P y=$ pyrite, $L-G=$ limonite-goethite, ht $=$ hematite. The bar scale is $5 \mu m$.

a positive correlation, $\mathrm{Au}-\mathrm{As}, \mathrm{Au}-\mathrm{Cu}$, and $\mathrm{Pb}-\mathrm{Ag}$ show no clear correlation (Fig. 9). The degree of correlation between trace elements is given in Table S1 (Supplementary file A). Gold shows a strong correlation with Mo and a low correlation with Ag. Principal component analysis was applied to the data and 5 components were generated, explaining about $95 \%$ of the variance (Table S2). Au is associated with component 4 and accounts for $5.15 \%$ of the total varibility. This component shows a moderate positive loading for $\mathrm{Ag}$, Ce, and Mo. 

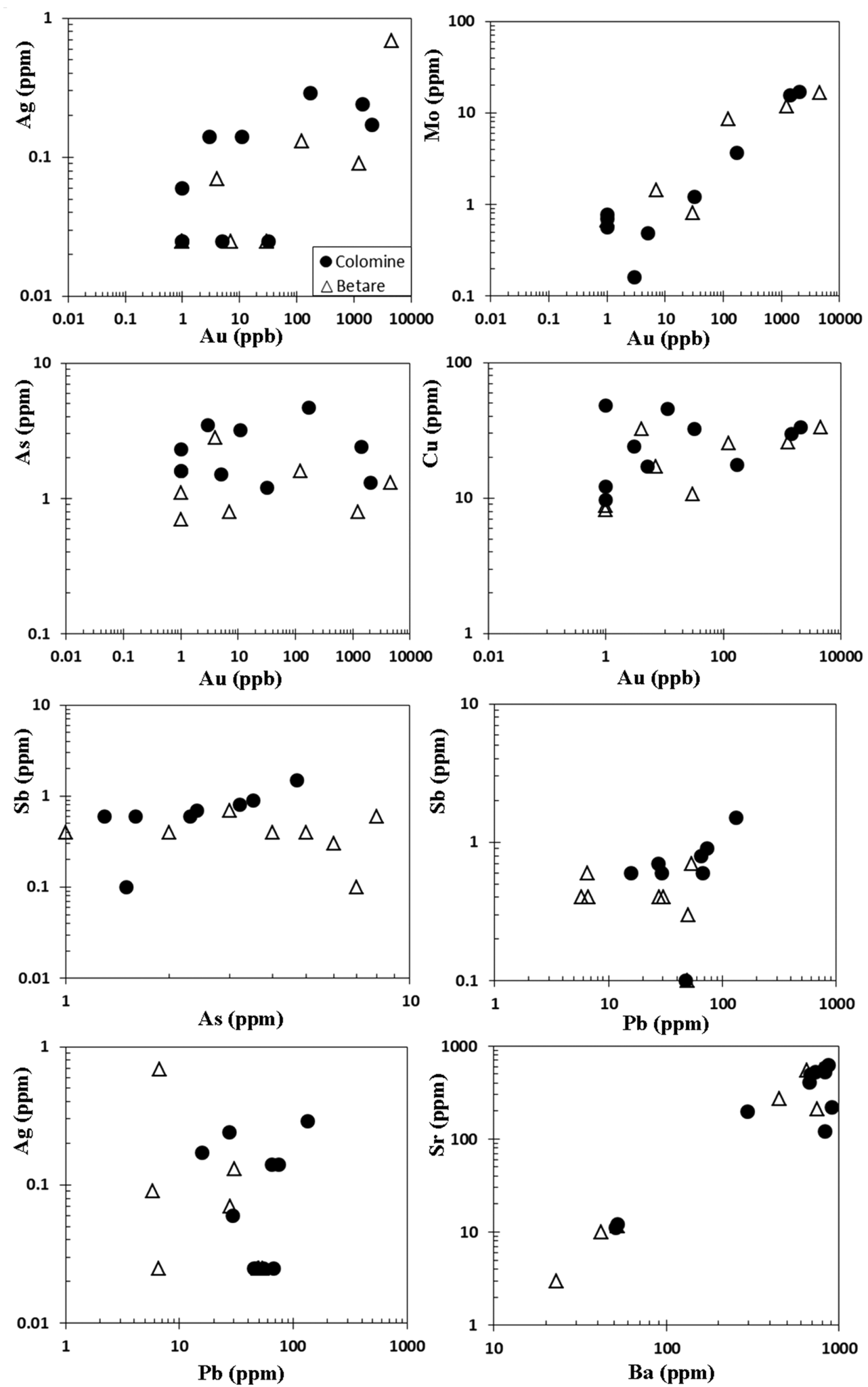

Figure 9. Variation of selected elemental concentrations in quartz vein and wall-rock samples from the Colomine and Bétaré Oya gold districts.

Wall-rock geochemical data from Ngatcha et al. (2019) shows the $\mathrm{Au}$ content in the range of 5-32 ppb. The concentration of $\mathrm{Ba}(683-$ 909 ppm), Mn (137-290 ppm), Cu (9.7-32.2 ppm), and Cs (1.19$6.54 \mathrm{ppm}$ ) is remarkable. $\mathrm{Ga}, \mathrm{Sc}, \mathrm{Sb}, \mathrm{Cr}$, and $\mathrm{Zn}$ show moderate concentrations. Ta values are low $(0.3-1.3 \mathrm{ppm})$, while the content of $\mathrm{W}$ and $\mathrm{Ag}$ are below detection limits. Using Pearson correlation, a geochemical association of $\mathrm{Au} \pm \mathrm{Y} \pm \mathrm{Cu} \pm \mathrm{Zn} \pm \mathrm{Mn}$ is revealed (Table S3). Although very low, $\mathrm{Au}$ is associated with component 2 with $35 \%$ variability and low positive loading for $\mathrm{Bi}, \mathrm{Cd}, \mathrm{Mn}, \mathrm{Pb}, \mathrm{Sb}, \mathrm{Tl}$, and $\mathrm{Zn}$ (Table S4). 

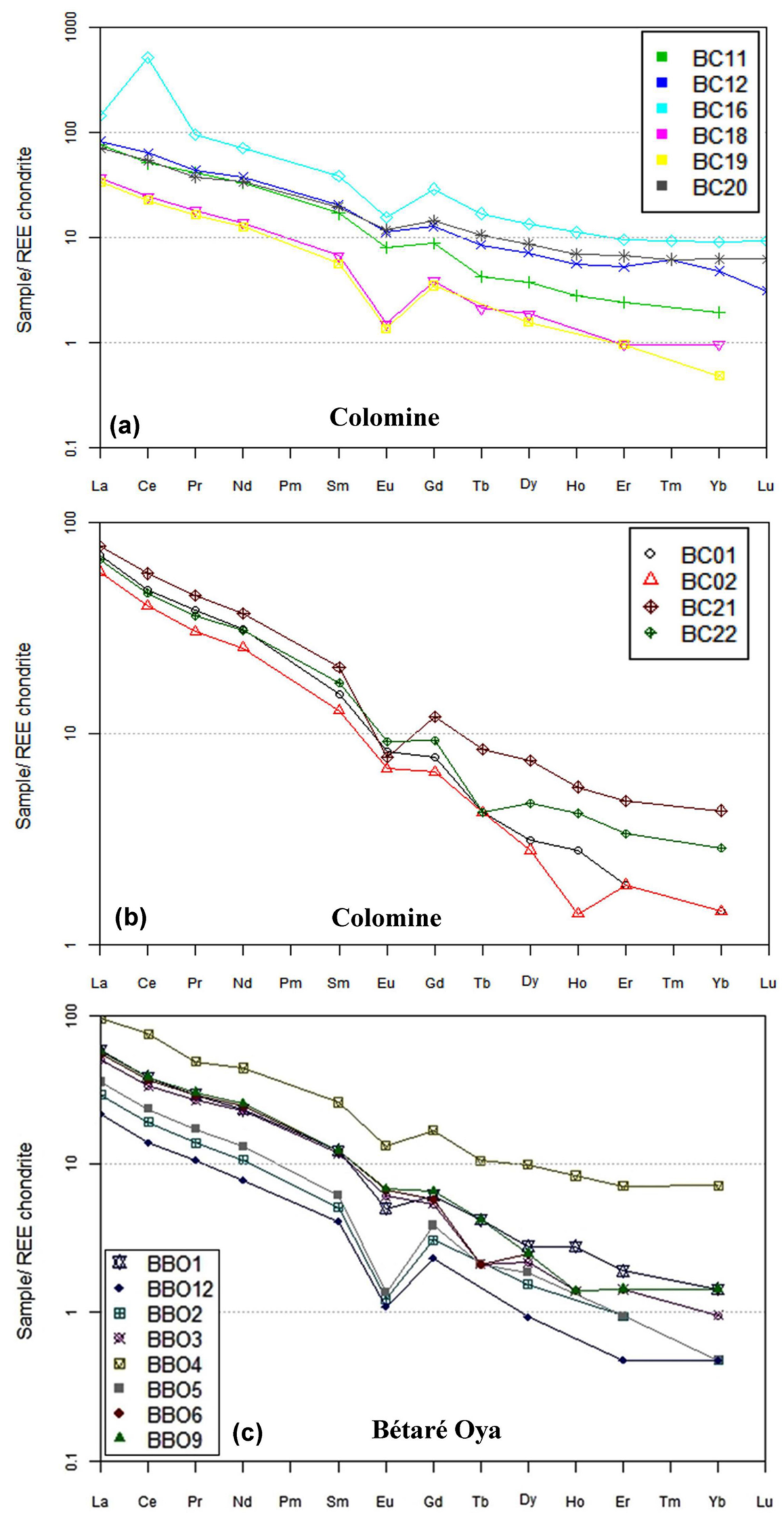

Figure 10. REE pattern for (a-b) quartz veins and (c) wall-rock from the Colomine and the Betare Oya gold districts, normalized to Boynton (1984) values. 
REE patterns for quartz veins and wall-rock, normalised to Boynton (1984) values, show high LREE concentrations relative to HREE (Fig. 10). The quartz veins (Fig. 10a) show slight positive $\mathrm{Gd}$ and negative Eu anomalies, with the mineralized veins (BC16, BC18, and $\mathrm{BC} 19)$ showing a stronger negative Eu anomaly. Concentrations of HREE are very low in the wall-rock samples (Fig. 10b), as indicated by a steep curve.

\section{Bétaré Oya gold district}

Whole-rock geochemical analysis of trace elements from quartz veins is presented in Table 1. Elemental concentrations in the quartz veins range from $\mathrm{Fe} 1.07-3.82 \mathrm{wt} \%$, Mg 0.01-0.17 wt $\%$, Na $0.03-$ $3.56 \mathrm{wt} \%$, K $0.12-3.11 \mathrm{wt} \%$, and $\mathrm{Ca} 0.01-1.03 \mathrm{wt} \%$. The gold content is higher here and ranges from $4-4600 \mathrm{ppb}$. In ppm, there are significant levels of Ag (0.07-0.69), As (0.7-2.8), Ba (23-804), Bi (0.08-0.59), Cr (15-65), Cu (8.5-33.3), Mn (49-844), Mo (0.0616.6), $\mathrm{Pb}$ (5.8-53.4), Ni (3.1-25.3), Rb (8.3-831), Sb (0.1-0.7), $\mathrm{Sr}$ (3-557), V (7-67), Zr (1.5-94), and Zn (1-61.4). The silver and arsenic content are generally low compared to base metals such as $\mathrm{Mn}$, $\mathrm{Co}, \mathrm{Ni}, \mathrm{Cu}$, and $\mathrm{Pb}$. $\mathrm{Au}-\mathrm{Ag}, \mathrm{Au}-\mathrm{Mo}, \mathrm{Au}-\mathrm{Cu}$, and $\mathrm{Ba}-\mathrm{Sr}$ show a positive correlation, while $\mathrm{Au}-\mathrm{As}, \mathrm{As}-\mathrm{Sb}, \mathrm{Pb}-\mathrm{Sb}$, and $\mathrm{Pb}-\mathrm{Ag}$ show no clear correlation (Fig. 9). Persons' linear correlation analysis shows a strong correlation between $\mathrm{Au}$ and $\mathrm{Ag}-\mathrm{Mo}-\mathrm{Cu}$ (Table S5). The principal component analysis applied to the data revealed 5 components explaining about $97 \%$ of the variance generated (Table S6). Au is associated with component 4 and accounts for $7.18 \%$ of the total variability. This component shows moderate positive loading for Ag, Mo, $\mathrm{Sb}, \mathrm{Sn}$, and $\mathrm{Tl}$.

REE-patterns (normalised to the values of Boynton, 1984) for quartz veins show enrichment in LREE and depletion in HREE, with negative Eu anomalies (Fig. 10c). Two patterns can be distinguished in these samples, one with a relatively strong negative $\mathrm{Eu}$ anomaly corresponding to the mineralized samples $(\mathrm{BBO} 2, \mathrm{BBO} 4, \mathrm{BBO} 5$, and $\mathrm{BBO} 12)$, and another with a relatively weak negative $\mathrm{Eu}$ anomaly shown by the barren veins (BBO1, BBO3, BBO6, and BBO9).

\section{Discussion}

\section{Structural Features and Timing of Gold Mineralization}

Several stages of fluid flow and deformation can be deduced from the different textural features of the mineralized and barren quartz veins. However, the challenge lies in determining the relative timing of the mineralized event. The gold occurrences in the investigated districts are associated with shear zones, with gold occurring in quartz veins within weathered schist units in the Bétaré Oya gold district and granitoids in the Colomine gold district, and disseminated in the hydrothermally altered wall-rock. The W-E to WNW-ESE, and N-S trends correspond to the barren massive quartz veins in the Colomine gold district. In the Bétaré Oya gold district, the barren veins trend NW-SE to N-S and are similar to the reported barren veins in the Batouri gold district (Suh et al., 2006). According to Kankeu et al. (2009), the NW-SE to N-S trending structures represent a post-D3 deformational stage (D4). Considering the timeframe proposed by $\mathrm{Li}$ et al. (2017) for the evolution of the Neoproterozoic Fold Belt of Cameroon, this corresponds to a time interval between ca. 580-560 Ma. The vuggy-brecciated-sheared gold-bearing quartz veins have a NNE-SSW to NE-SW trend in both gold districts. This is equally similar to the trend documented in the previous work of Vishiti et al. (2017) in the Bétaré Oya gold district and that of Suh et al. (2006) in the Batouri gold district. Across the national border in the Pala region of southwestern Chad, a similar trend is also proposed for the goldbearing veins (Tchameni et al., 2013). This implies that the shearing stage hosting the mineralization was of regional scale and its timing is closely related to the formation or reactivation of NE-SW-trending shear zones such as the CCSZ, BOSZ, and SSZ (Suh et al., 2006; Kankeu et al., 2009).

The differences in the hosting lithologies from the Bétaré Oya gold district to the Colomine gold district reflect a separate timing of gold mineralization. Granitoids plutonism dated at about $635 \mathrm{Ma}$ (early Pan-African) in the Bétaré Oya gold district is inferred to be related to gold mineralization (Ateh et al., 2017). Their emplacement could have been associated with the circulation of the ore-bearing fluids that produced locally silicified gold-bearing veins along the cleavage planes in schist units. This is in line with the timing of about $620-640$ $\mathrm{Ma}$ (zircon U-Pb dating) proposed by Asaah et al. (2014) for intrusion-related gold mineralization in the Batouri gold district. This timeframe corresponds to the second deformation event along the CASZ, characterised by crustal shortening and low-pressure metamorphism.

This early mineralization stage is probably absent or yet to be identified in the Colomine gold district. Deformation in the Colomine gold district can be described as having evolved via a brittle-ductile scenario. It can be summarized as comprising initially of host granitoids formed by partial melting and fractionation (Ngatcha et al., 2019) dated at about 617-543 Ma using the K-Ar dating technique on biotite separates and whole-rock samples (Fuh, 1990). The host granitoids later experienced fracturing and shearing, intensely at the margins. These sheared granite wall-rocks are mineralized and are characterised by a phyllic-like alteration assemblage of sericite-muscovite + biotite + chlorite + quartz, typical of the greenschist facies (Bucher and Frey, 2002). Such pervasive gold mineralization with disseminated gold content up to $107 \mathrm{ppm}$ in the wall-rock is equally described in the Batouri gold district (Tata et al., 2018). This event may not have been associated with the emplacement of the pluton. This shearing stage most likely corresponds to the ENE-trending ductile shearing D3 phase described by Kankeu et al. (2009) in the Bétaré Oya gold district as responsible for the generation of mylonites in granitoids. Based on the geochronological framework proposed by $\mathrm{Li}$ et al. (2017), this corresponds to a time interval between ca. 590-580 Ma. This is slightly similar to the time interval of 562-543 \pm 14 Ma proposed by Fuh (1990) for gold mineralized lithologies (quartz-sericite \pm tourmaline mylonites) in Colomine. Although argon loss by the K-Ar dating technique during tectonic deformation usually makes this technique imprecise (Kelley, 2002), it is clear that this stage was associated with an influx of hydrothermal fluids containing silica, gold, and sulphide (Fig. 11).

According to Fuh (1990), late granitic evolution in the Colomine area developed a residual fluid phase in which incompatible elements (such as $\mathrm{Ba}, \mathrm{Rb}, \mathrm{Hf}, \mathrm{B}$ ) and Au were partitioned. Quartz tourmaline veins documented by the author in this area are probably the result of 


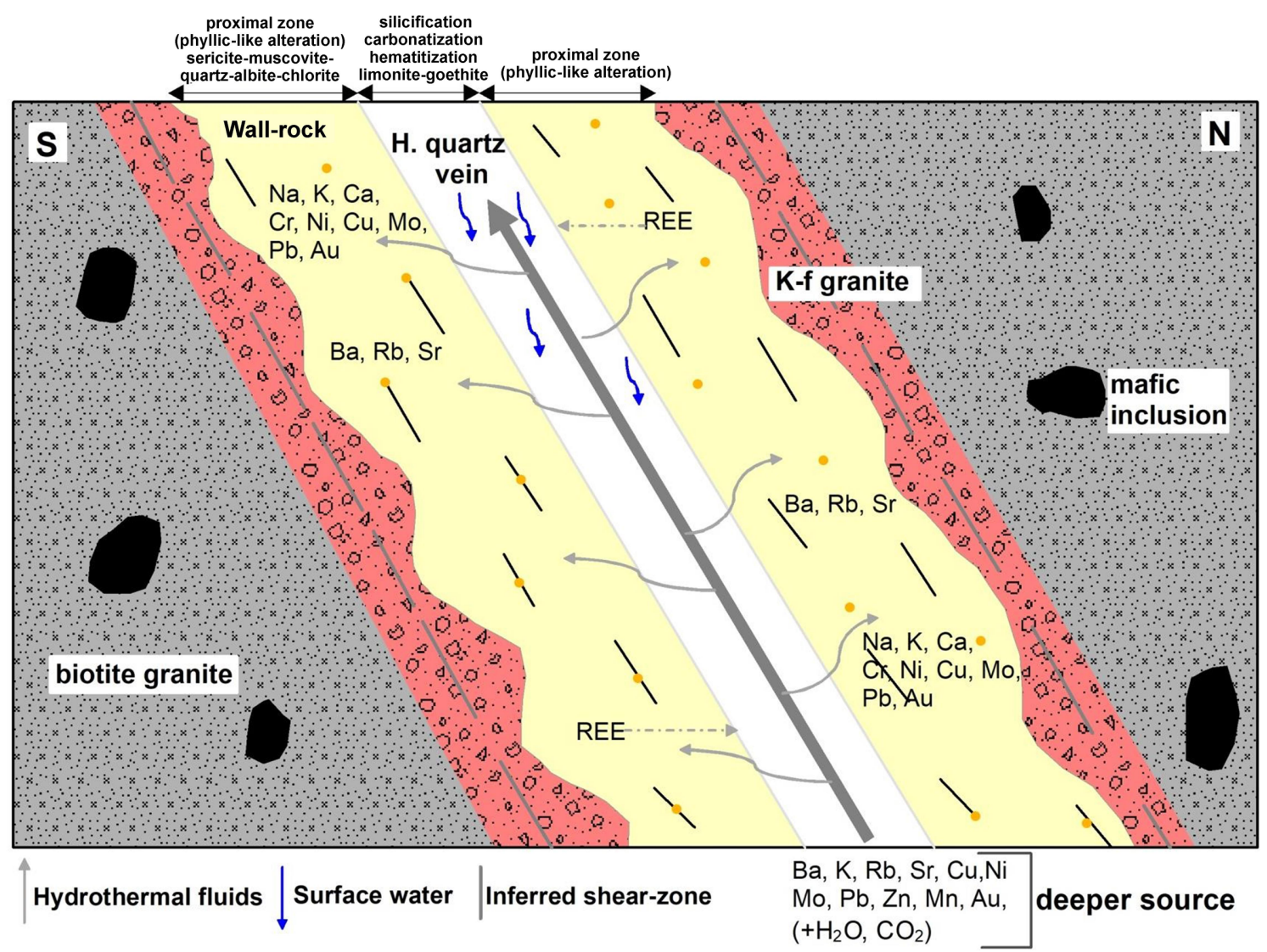

Figure 11. A schematic illustration of the hydrothermal alteration scenario at Colomine. Alteration zones and element exchange are shown (modified from Asaah, 2010). K-f granite = potassium feldspar granite, H-quartz vein = hydrothermal quartz vein.

this fluid phase. As is typical of tropical environments, weathering and oxidation processes led to the formation of hematite, limonite, and goethite within the quartz veins. The presence of euhedral crystalline hematite pseudomorphs resulting from oxidation of magnetite (martitization) indicates the dominance of oxidation in this area. Moreover, botryoidally altered hematite indicates a supergene stage. Thus, it may be inferred that shear zone-related ductile-brittle deformation and remobilisation may be the dominant event behind the observed gold dissemination in altered granites in SE Cameroon. The presence of micro-faulting with a slight displacement of the laminations/quartz veinlets indicates the presence of a late brittle event after the ductile phase. This was probably associated with micro-fracturing and focused infiltration of ore fluids. The frequent occurrence of oxidation along such fractures suggests the presence of an ore-bearing fluid. According to Suh et al. (2006), infiltration of gold-bearing fluid may have been facilitated during this ductile phase to produce disseminated gold mineralization.

\section{Alteration and Geochemical Characteristics}

Alteration processes in the Colomine and Bétaré Oya gold districts include feldsparthization, sericitization, carbonatization, silicification, sulfidation, hematitization, and limonite-goethite alteration (supergene stage). Typically, in the Colomine gold district, there is an alteration envelope from the wall-rock towards the mineralized vein (Fig. 11). The mineralized vein itself is characterised by silicification, sulfida- tion, hematitization, and limonite-goethite alteration. This is consistent with the proposed stage 1 and 2 mineralization associated with gold in the district described by Ndonfack et al. (2021). The alteration boundary between the quartz vein and the wall-rock is not always distinct, as some veins are usually sericitized. The Batouri gold district (Suh et al., 2006; Tata et al., 2018) and the Bétaré Oya gold district, this study (Figs. 7 and 8) and previous work by Vishiti et al. (2017) also document similar alteration features. This style of alteration is typical of most mesothermal/orogenic hydrothermal systems (Vishiti et al., 2017), which transition from an outer porpylitic assemblage (chlorite-carbonate) to an innermost silica-sulphide zone. However, the progressive increase in gold content from the distal to the proximal zone noted in this study and similar work in the Batouri area (Tata et al., 2018) is more indicative of an intrusion-related system.

In the Colomine gold district, sulphur isotope $\left(\delta^{34} \mathrm{~S} ; 6.5\right.$ to $7.0 \%$ ), oxygen isotope $\left(\delta^{18} \mathrm{O}\right)$, and fluid inclusion data $\left(\delta \mathrm{D}\right.$ and $\left.\delta^{13} \mathrm{C}\right)$ for pyrite-gold-bearing quartz veins have been used to suggest a metamorphic source for sulphide and ore-forming fluids (Ndonfack et al., 2021). The contribution of the mantle and/or magmatic source(s) to the bulk fluids and metal budget that form the gold system cannot be ruled out, since the intrusions are related to gold mineralization (Ngatcha et al., 2019; Takodjou Wambo et al., 2020). The elevated content of base metals such as $\mathrm{Pb}, \mathrm{Mn}$, and $\mathrm{Zn}$ obtained from the gold-bearing quartz veins in this study, including the Au-Ag-Mo geochemical association, is interpreted to reflect a granitic/magmatic source of the mineralizing fluids. This is considered to be the source of sulphide. 
The gold-bearing hydrothermally altered wall-rock is equally characterised by a similar base metal controlling factor (Y-Cu-Zn-Mn). This was probably a granitic fluid that evolved through fractionation, as reflected by the REE pattern of the gold-bearing veins (Fig. 10). These geochemical associations are typical of porphyry deposits $\mathrm{Cu}-\mathrm{Au}-\mathrm{Mo}$, where both ore-forming fluid and metals are derived from the granite porphyry (e.g., Mao et al., 2011; Maghsoudi et al., 2014). The hematitization and limonite-goethite alteration characterising the mineralized quartz veins indicate that the magmatic-hydrothermal fluids derived from the magma in the early stages of the mineralization event were mixed with meteoric waters in the late stages.

In the Bétaré Oya gold district, the gold-bearing quartz veins reflect an Au-Ag-Cu-Mo geochemical association, indicating that, the sulphide and ore metals were derived from the magma. Previous work on mineralized quartz veins in the district indicates an $\mathrm{Au} \pm \mathrm{Cu} \pm \mathrm{Bi} \pm \mathrm{As} \pm$ $\mathrm{Pb}$ geochemical association with elevated content of base metals such as $\mathrm{Pb}$ and $\mathrm{Zn}$ (Vishiti et al., 2017). Sulphur isotopes from the same veins indicated a wide range in $\delta^{34} \mathrm{~S}$ from 2.8 to $14.9 \%$ pointing to multiple sources of sulphur in the system and interpreted as a mixture of sulphur from the metasedimentary and the granitic rocks (Vishiti et al., 2017). The similar REE fractionation patterns with negative $\mathrm{Eu}$ anomaly shown by mineralized quartz veins in the Colomine gold district are equally observed from mineralized quartz veins of the Bétaré Oya gold district. The obvious scenario is that both metals and fluids may be products of the same deep-crustal or even mantle-generated, thermal event (Goldfarb et al., 2005), prior to local remobilization by subsequent metamorphic fluids (Ndonfack et al., 2021).

\section{Conclusions}

The following conclusions could be made from this study;

1. The mineralized veins in the Colomine and the Bétaré Oya gold districts are vuggy, brecciated, and sheared. They are characterised by silicification, sulphidation, carbonatization, hematitization, and limonite-goethite alteration. Sericitization was only observed in mineralized veins of the Bétaré Oya gold district. Hematitization is the main alteration phase associated with gold mineralization in quartz veins and should serve as a guide to the miming artisans.

2. Primary gold occurrences in the Colomine and Bétaré districts are confined to NNE-SSW to NE-SW trending quartz veins hosted by altered granites and weathered schist, respectively. This trend corresponds to the second deformation event related to the formation or reactivation of the NE-SW trending CCSZ. The gold-bearing pervasive hydrothermal alteration observed in Colomine occurred during the ENE-trending ductile D3 phase responsible for the generation of mylonitized granitoids. The barren quartz veins in both gold districts trend NW-SE to N-S, representing a post-D3 deformational stage (D4).

3. Brittle-ductile deformation development in the Colomine gold district consists initially of host granitoid formation by partial melting and fractionation, followed by fracturing and shearing, intense at the contact with the weathered schist units. These zones of weakness enabled the influx of hydrothermal fluids from which incompatible elements such as $\mathrm{Cu}, \mathrm{Mo}, \mathrm{Pb}, \mathrm{Zn}, \mathrm{Mn}$, and $\mathrm{Au}$ were partitioned. Subsequent oxidation processes led to the formation of hematite, limonite, and goethite. This hydrothermal fluid led to the formation of sericite- muscovite alteration minerals within the altered granite wall-rock, associated with gold-bearing fluid infiltration and disseminated mineralization. A phyllic-like alteration assemblage of sericite-muscovite + biotite + chlorite + quartz, a typical mineral assemblage of the greenschist facies, characterised the wall-rock. This alteration could equally serve as a guide for low-grade gold exploration.

4. The bulk trace element signature of the mineralized veins in the Colomine and the Bétaré Oya gold districts depicts a geochemical association of $\mathrm{Au}-\mathrm{Ag}-\mathrm{Mo}$ and $\mathrm{Au}-\mathrm{Ag}-\mathrm{Mo}-\mathrm{Cu}$, respectively. The positive correlation of gold with base metals such as $\mathrm{Cu}$ and $\mathrm{Mo}$ and the increased content of $\mathrm{Zn}, \mathrm{Pb}, \mathrm{Ba}$, and $\mathrm{Mn}$ in these gold districts reflect a magmatic/granitic source of the ore-bearing fluids with which sulphides are associated. REE plots are also consistent with fractionation from a granitic melt. The fractionation process probably triggered the precipitation of $\mathrm{Au}$ and base metals.

\section{Acknowledgments}

This work is part of the Ph.D. and M.Sc. theses of the first and third authors, respectively. C.E.S. is grateful for the funding from IUGS. Support from the ANESI-UNESCO student exchange mobility grant for the research stay of R.B.N. at the analytical facility of the University of Johannesburg, facilitated by Prof. Axel Hoffman, is also acknowledged. This contribution is part of the project funded by the IUGS under the 'Resourcing Future Generations' scheme coordinated at University of Buea by C.E.S. Discussions with Dr. Akumbom Vishiti with insights into the field study are much appreciated. This manuscript benefited significantly from comprehensive reviews of Episodes anonymous reviewers and the Editor-in-Chief, Prof. Jin-Yong Lee.

\section{References}

Asaah, A.V., Zoheir, B., Lehmann, B., Frei, D., Burgess, R., and Suh, C.E., 2014 , Geochemistry and geochronology of the $\sim 620$ Ma gold-associated Batouri granitoids, Cameroon. International Geology Reviews, v. 57, pp. 1485-1509.

Ateh, K.I., Suh, C.E., Shemang, E.M., Vishiti, A., Tata, E., and Chombong, N.N., 2017, New LA-ICP-MS U-Pb Ages, Lu-Hf Systematics and REE Characterization of Zircons from a Granitic Pluton in the Bétaré Oya Gold District, SE Cameroon. Journal of Geosciences and Geomatics, v. 5, pp. 267-283.

Boynton, W.V., 1984, Cosmochemistry of the rare earth elements: meteorite studies. In: Developments in geochemistry. Elsevier, v. 2, pp. 63114.

Bucher, K., and Frey, M., 2002, Metamorphism of Granitoid Rocks. In: Bucher, K., and Frey, M. (Eds.), Petrogenesis of Metamorphic Rocks ( $8^{\text {th }}$ edition). Springer, Heidelberg, Berlin, pp. 329-334.

Castaing, C., Feybesse, J.A., Thiéblemont, D., Triboulet, C., and Chevremont, P., 1994, Palaeogeographical reconstructions of the Pan-African/ Brasilianoorogen: closure of an oceanic domain or intracontinental convergence between major blocks?. Precambrian Research, v. 69, pp. 327-344.

de Wit, M.J., Stankiewicz, J., and Reeves, C., 2008, Restoring Pan-African-Brasiliano connections: more Gondwana control, less trans-Atlantic corruption. Geological Society, London, Special Publications, v. 294, pp. 399-412.

Deksissa, D.J., and Koeberl, C., 2004, Geochemistry, alteration, and gene- 
sis of gold mineralization in the Okote area, southern Ethiopia. Geochemical Journal, v. 38, pp. 307-331.

Fuh, C.G., 1990, The geochemical and structural controls on gold mineralization in the Colomine area: Pan-African belt of eastern Cameroon (Ph.D. thesis). University of London, London, 268 p.

Gazel, J., and Gérard, G., 1954, Carte géologique de reconnaissance du cameroun au 1/500 000, feuille Batouri-Est avec notice explicative; Mémoire Direction des Mines et de la Géologie, Yaoundé, Cameroun.

Goldfarb, R.J., Baker, T., Dubé, B., Groves, D.I., Hart, C.J.R., and Gosselin, P., 2005, Distribution, character, and genesis of gold deposits in metamorphic terranes. In: Hedenquist, J.W., Thompson, J.F.H., Goldfarb, R.J., and Richards, J.P. (Eds.). Society of Economic Geologists, Inc, pp. 407-450.

Gouet, D.H., Ndougsa-Mbarga, T., Meying, A., Assembe, A.P., and ManMvele Pepogo, A.D., 2013, Gold Mineralization Channels Identification in the Tindikala-Boutou Area (Eastern-Cameroon) Using Geoelectrical (DC \& IP) Methods: A Case Study. International Journal of Geosciences, v. 4, pp. 643-655.

Houketchang Bouyo, M., Penaye, J., Njel, U.O., Sep, J.P.N., Nyama, B.A., Wassouo, W.J., Abate, J.M.E., Yaya, F., Mahamat, A., Ye Hao, and Wu Fei, 2016, Geochronological, geochemical and mineralogical constraints of emplacement depth of TTG suite from the Sinassi Batholith in the Central African Fold Belt (CAFB) of northern Cameroon: Implications for tectonomagmatic evolution. Journal of African Earth Sciences, v. 116, pp. 9-41.

Kalliomäki, H., Wagner, T., Fusswinkel, T., and Sakellaris, G., 2017, Major and trace element geochemistry of tourmalines from Archean orogenic gold deposits: Proxies for the origin of gold mineralizing fluids?. Ore geology reviews, v. 91, pp. 906-927.

Kankeu, B., Greiling, R.O., and Nzenti, J.P., 2009, Pan-African strike-slip tectonics in eastern Cameroon Magnetic fabrics (AMS) and structures in the Lom Basin and its gneissic basement. Precambrian Research, v. 174, 258-272.

Kelley, S., 2002, K-Ar and Ar-Ar dating. Reviews in Mineralogy and Geochemistry, v. 47, pp. 785-818.

Khant, W., Warmada, I.W., Idrus, A., Satijadji, L.D., and Watanabe, K., 2012, Alteration Mineralogy and Quartz Textures of Polymetallic Epithermal Quartz Veins at Soripesa Prospect Area, Sumbawa Island, Indonesia. 2nd Asia Africa Mineral Resources Conference Bundung, pp. 14-17.

Kwékam, M., Liégeois, J.P., Njonfang, E., Affaton, P., Hartmann, G., and Tchoua, F., 2010, Nature, origin and significance of the Fomopéa PanAfrican high-K calc-alkaline plutonic complex in the Central African fold belt (Cameroon). Journal of African Earth Sciences, v. 57, pp. 79-95.

Li, X.H., Chen, Y., Tchouankoue, J.P., Liu, C.Z., Li, J., Ling, X.X., Tang, G.O., and Liu, Y., 2017, Improving geochronological framework of the Pan-African orogeny in Cameroon: New SIMS zircon and monazite U$\mathrm{Pb}$ age constraints. Precambrian Research, v. 294, pp. 307-321.

Maghsoudi, A., Yazdi, M., Mehrpartou, M., Vosoughi, M., and Younesi, S., 2014, Porphyry $\mathrm{Cu}-\mathrm{Au}$ mineralization in the Mirkuh Ali Mirza magmatic complex, NW Iran. Journal of Asian Earth Sciences, v. 79, pp. 932-941.

Mao, J., Zhang, J., Pirajno, F., Ishiyama, D., Su, H., Guo, C., and Chen, Y., 2011, Porphyry $\mathrm{Cu}-\mathrm{Au}-\mathrm{Mo}$-epithermal $\mathrm{Ag}-\mathrm{Pb}-\mathrm{Zn}$-distal hydrothermal Au deposits in the Dexing area, Jiangxi province, East China - a linked ore system. Ore Geology Reviews, v. 43, pp. 203-16.

Milési, J.P., Toteu, S.F., Deschamps, Y., Feybesse, J.L., Lerouge, C., Cocherie, A., Penaye, J., Tchameni, R., Moloto-A-Kenguemba, G., Kampunzu, H.A.B., Nicol, N., Duguey, E., Leistel, J.M., Saint-Martin, M., Ralay, F., Heinry, C., Bouchot, V., Doumnang Mbaigane, J.C., Kanda Kula, V., Chene, F., Monthel, M., Boutin, B., and Cailteux, J., 2006, An overview of the geology and major ore deposits of Central Africa: Explanatory note for the 1:4000, 000 map "Geology and major ore deposits of Central Africa”. Journal of African Earth Sciences, v. 44, pp. 571-595.
Mosoh Bambi, C.M., Frimmel, H.E., Zeh, A., and Suh, C.E., 2013, Age and origin of Pan-African granites and associated U-Mo mineralization at Ekomedion, southwestern Cameroon. Journal of African Earth Sciences, v. 88, pp. 15-37.

Ndonfack, A.K.I., Xie, Y., and Goldfarb, R., 2021, Gold occurrences of the Woumbou-Colomine-Kette district, eastern Cameroon: ore-forming constraints from petrography, SEM-CL imagery, fluid inclusions, and C-O-H-S isotopes. Mineralium Deposita. https://doi.org/10.1007/ s00126-021-01050-7

Ngatcha, R.B., Okunlola, O.A., Suh, C.E., Ateh, K.I., and Hofmann, A., 2019, Petrochemical characterization of Neoproterozoic Colomine granitoids, SE Cameroon: Implications for gold mineralization. Lithos, v. 344-345, pp. 175-192.

Ngnotue, T., Ganno, S., Nzenti, J.P., Schulz, B., Tchaptchet, T.D., and Suh, C.E., 2012, Geochemistry and geochronology of Peraluminous high-K granitic leucosomes of Yaoundé series (Cameroon): evidence for unique Pan-African magmatism and melting event in the north equatorial fold belt. International Journal of Geoscience, v. 3, pp. 525-548.

Njome, M.S., and Suh, C.E., 2005, Tectonic evolution of the Tombelgraben basement, southwestern Cameroon. Episodes-News magazine of the International Union of Geological Sciences, v. 28, pp. 31-41.

Penaye, J., Kröner, A., Toteu, S.F., Van Schmus, W.R., and Doumnang, J.C., 2006, Evolution of the Mayo Kebbi region as revealed by zircon dating: an early (ca. $740 \mathrm{Ma}$ ) Pan-African magmatic arc in southwestern Chad. Journal of African Earth Sciences, v. 44, pp. 530-542.

Sarangi, S., Srinivasan, R., and Balaram, V., 2013, REE geochemistry of auriferous quartz-carbonate veins of Neoarchean Ajjanahalli gold deposit, Chitradurga schist belt, Dharwar Craton, India. Geoscience Frontiers, v. 4, pp. 231-239.

Suh, C.E., Lehmann, B., and Mafany, G.T., 2006, Geology and geochemical aspects of lode gold mineralization at Dimako-Mboscorro, SE Cameroon. Geochemistry: Exploration, Environment, Analysis, v. 6, pp. 295-309.

Takodjou Wambo, J.D., Ganno, S., DjonthuLahe, Y.S., KouankapNono, G.D., Fossi, D.H., Tchouatcha, M.S., and Nzenti, J.P., 2018, Geostatistical and GIS analysis of the spatial variability of alluvial gold content in Ngoura-Colomines area, Eastern Cameroon: Implications for the exploration of primary gold deposit. Journal of African Earth Sciences, v. 142, pp. 138-157.

Takodjou Wambo, J.D., Ganno, S., Ngambu, A.A., Negue, E.N., Ondoa, J.M., and Nzenti, J.P., 2016, Use of Landsat 7 ETM+ Data for the Geological Structure Interpretation: Case Study of the Ngoura-Colomines Area, Eastern Cameroon. Journal of Geosciences and Geomatics, v. 4, pp. 61-72.

Takodjou Wambo, J.D., Pour, A.B., Ganno, S., Asimow, P.D., Zoheir, B., Salles, R.D.R., Nzenti, J.P., Pradhan, B., and Muslim, A.M., 2020, Identifying high potential zones of gold mineralization in a sub-tropical region using Landsat- 8 and ASTER remote sensing data: A case study of the Ngoura-Colomines goldfield, eastern Cameroon. Ore Geology Reviews, v. 122, pp. 103-530. https://doi.org/10.1016/j.oregeorev.2020. 103530

Tata, E., Suh, C.E., Vishiti, A., Shemang, E.M., Fon, A.N., Ateh, K.I., and Chombong, N.N., 2018, Wallrock alteration categories and their geochemical signatures in gold-bearing Neoproterozoic granitoids, Batouri gold district, southeastern Cameroon. Geochemistry: Exploration, Environment, Analysis. https://doi.org/10.1144/geea2016-017

Tchameni, R., Doumnang, J.C., Deudibaye, M., and Branquet, Y., 2013, On the occurrence of gold mineralization in the Pala Neoproterozoic formations, South-Western Chad. Journal of African Earth Sciences, v. 84, pp. 36-46.

Toteu, S.F., Penaye, J., and Djomani, Y.P., 2004, Geodynamic evolution of the Pan-African belt in central Africa with special reference to Cameroon. Canadian Journal of Earth Sciences, v. 41, pp. 73-85.

Toteu, S.F., Penaye, J., Deloule, E., Van Schmus, W.R., and Tchameni, R., 2006, Diachronous evolution of volcano-sedimentary basins north of 
the Congo craton: Insights from $\mathrm{U}-\mathrm{Pb}$ ion microprobe dating of zircons from the Poli, Lom and Yaoundé Groups (Cameroon). Journal of African Earth Sciences, v. 44, pp. 428-442.

Van Schmus, W.R., Oliveira, E.P., Da Silva Filho, A.F., Toteu, S.F., Penaye, J., and Guimarães, I.P., 2008, Proterozoic links between the Borborema Province, NE Brazil, and the Central African fold belt. Geological Society, London, Special Publications, v. 294, pp. 69-99.

Vishiti, A., Suh, C.E., Lehmann, B., Shemang, E.M., Ngome, N.L.J., Nshanji,

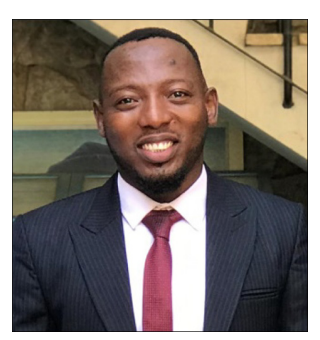

Ralain Bryan Ngatcha is a scholar and alumni of the PAULESI, University of Ibadan, Nigeria, and a Ph.D holder in Mineral Exploration Geoscience. He is currently an assistant lecturer in Petrology, Geochemistry, and Geochronology at The University of Bamenda.

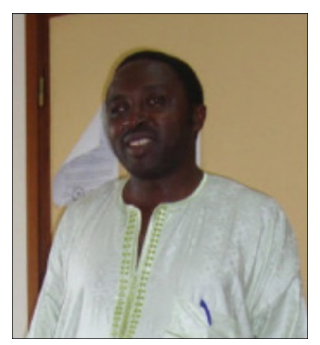

Cheo Emmanuel Suh is a Professor of Economic Geology and Microtectonics and a Humboldt Fellow. He is also a mining consultant in Cameroon and the Deputy ViceChancellor: Teaching, Professionalization and Development of ICT at The University of Bamenda.

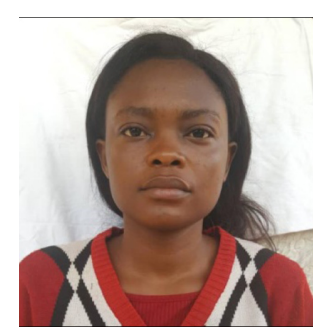

Fongyen Naclyn Kah is an M.Sc. holder in Applied Geology from The University of Bamenda. Her research interests are on structural controls of gold mineralisation.
N.J., Chinjo, F.E., Mongwe, O.Y., Egbe, A.J., and Petersen, S., 2017, Mineral chemistry, bulk rock geochemistry, and S-isotope signature of lode-gold mineralization in the Bétaré Oya gold district, south-east Cameroon. Geological Journal, pp. 1-18.

Vishiti, A., Etame, J., and Suh, C.E., 2019, Features of gold-bearing quartz veins in an artisanal mining-dominated terrain, Batouri gold district, Eastern region of Cameroon. Episodes, v. 42, pp. 199-212.

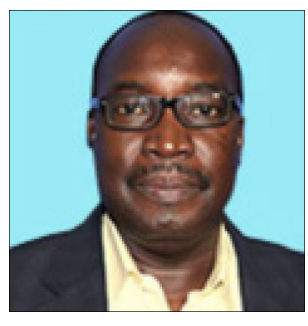

Elisha Mutum Shemang is full Professor of Geosciences and Dean of Postgraduate Studies at the Botswana International University of Science and Technology. His main research interest centres on geophysics and environmental geology/climate change.

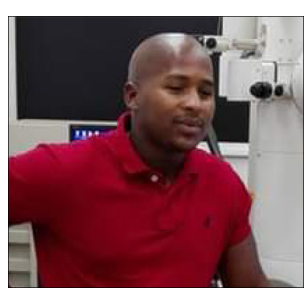

Siyasanga Mpelane is an Instrument Scientist who specialises in TEM and SEM at the Spectrum Analytical Facility of the University of Johannesburg. 